Provided for non-commercial research and education use. Not for reproduction, distribution or commercial use.

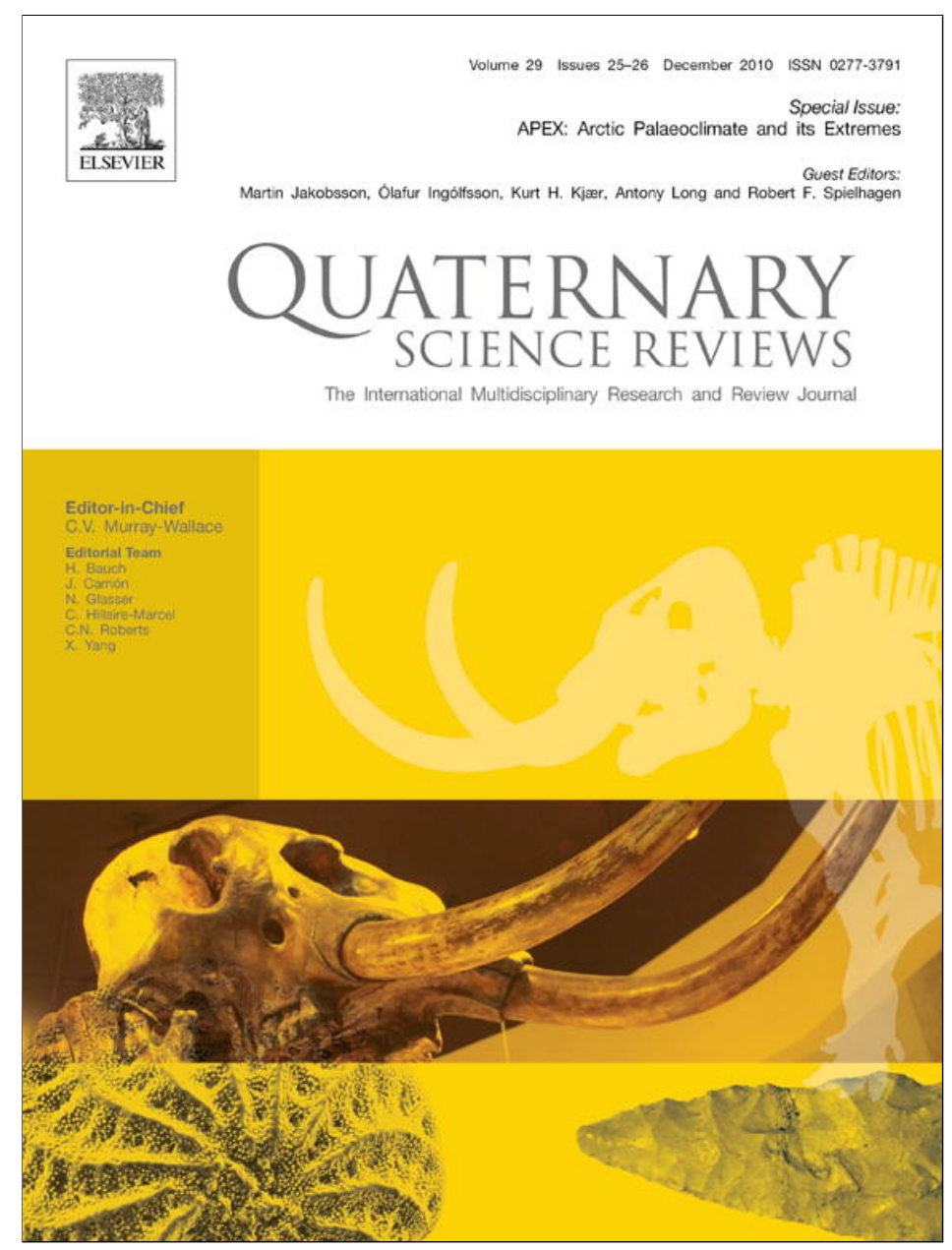

This article appeared in a journal published by Elsevier. The attached copy is furnished to the author for internal non-commercial research and education use, including for instruction at the authors institution and sharing with colleagues.

Other uses, including reproduction and distribution, or selling or licensing copies, or posting to personal, institutional or third party websites are prohibited.

In most cases authors are permitted to post their version of the article (e.g. in Word or Tex form) to their personal website or institutional repository. Authors requiring further information regarding Elsevier's archiving and manuscript policies are encouraged to visit:

http://www.elsevier.com/copyright 


\title{
High-resolution geophysical observations of the Yermak Plateau and northern Svalbard margin: implications for ice-sheet grounding and deep-keeled icebergs
}

\author{
J.A. Dowdeswell ${ }^{\mathrm{a}, *}$, M. Jakobsson ${ }^{\mathrm{b}}$, K.A. Hogan ${ }^{\mathrm{a}}$, M. O’Regan $^{\mathrm{b}}$, J. Backman ${ }^{\mathrm{b}}$, J. Evans ${ }^{\mathrm{c}}$, B. Hell ${ }^{\mathrm{b}}$, \\ L. Löwemark ${ }^{b}$, C. Marcussen ${ }^{d}$, R. Noormets ${ }^{e}$, C. Ó Cofaigh ${ }^{f}$, E. Sellén ${ }^{b}$, M. Sölvsten ${ }^{g}$ \\ ${ }^{a}$ Scott Polar Research Institute, University of Cambridge, Cambridge CB2 1ER, UK \\ ${ }^{\mathrm{b}}$ Department of Geological Sciences, Stockholm University, 10691 Stockholm, Sweden \\ ${ }^{\mathrm{c}}$ Department of Geography, Loughborough University, Loughborough LE11 3TU, UK \\ ${ }^{\mathrm{d}}$ Geological Survey of Denmark and Greenland, Øster Voldgate 10,1350 Copenhagen, Denmark \\ ${ }^{\mathrm{e}}$ The University Centre in Svalbard, Longyearbyen N-9171, Norway \\ ${ }^{\mathrm{f}}$ Department of Geography, Durham University, Durham DH1 3LE, UK \\ ${ }^{\mathrm{g}}$ Royal Danish Administration of Navigation and Hydrography, Overgaden o. Vandet 62B, P.O. Box 1919, 1023 Copenhagen K, Denmark
}

\section{A R T I C L E I N F O}

\section{Article history:}

Received 29 November 2009

Received in revised form

26 March 2010

Accepted 3 June 2010

\begin{abstract}
A B S T R A C T
High-resolution geophysical evidence on the seafloor morphology and acoustic stratigraphy of the Yermak Plateau and northern Svalbard margin between $79^{\circ} 20^{\prime}$ and $81^{\circ} 30^{\prime} \mathrm{N}$ and $5^{\circ}$ and $22^{\circ} \mathrm{E}$ is presented. Geophysical datasets are derived from swath bathymetry and sub-bottom acoustic profiling and are combined with existing cores to derive chronological control. Seafloor landforms, in the form of ice-produced lineations, iceberg ploughmarks of various dimensions (including features over $80 \mathrm{~m}$ deep and down to about $1000 \mathrm{~m}$ ), and a moat indicating strong currents are found. The shallow stratigraphy of the Yermak Plateau shows three acoustic units: the first with well-developed stratification produced by hemipelagic sedimentation, often draped over a strong and undulating internal reflector; a second with an undulating upper surface and little acoustic penetration, indicative of the action of ice; a third unit of an acoustically transparent facies, resulting from debris flows. Core chronology suggests a MIS 6 age for the undulating seafloor above about $580 \mathrm{~m}$. There are several possible explanations, including: (a) the flow of a major grounded ice sheet across the plateau crest from Svalbard (least likely given the consolidation state of the underlying sediments); (b) the more transient encroachment of relatively thin ice from Svalbard; or (c) the drift across the plateau of an ice-shelf remnant or megaberg from the Arctic Basin. The latter is our favoured explanation given the evidence currently at our disposal.
\end{abstract}

(c) 2010 Elsevier Ltd. All rights reserved.

\section{Introduction}

The Fram Strait is the only deep-water gateway between the Arctic Ocean and the North Atlantic (Fig. 1a). The Yermak Plateau and northern Svalbard margin are located on the eastern side of the Strait, thus occupying a position that is key to the understanding of the transfer of ice and water between the Arctic Ocean and the North Atlantic during the Quaternary (e.g. Spielhagen et al., 2004; Knies, et al., 2007). Ice sheets appear to have advanced across the Plateau only occasionally during the Quaternary, suggesting that it is inundated only in the most extensive glaciations. Earlier marinegeological and -geophysical investigations have shown evidence for the former presence of grounded ice on the Yermak Plateau,

\footnotetext{
* Corresponding author. Tel.: +441223 336541.

E-mail address: jd16@cam.ac.uk (J.A. Dowdeswell).
}

together with seafloor ploughmarks produced by deep-keeled icebergs (Vogt et al., 1994; Kristoffersen et al., 2004). However, both the timing and interpretation of these events has been difficult to constrain (e.g. Flower, 1997; Kristoffersen et al., 2004; Knies et al., 2007). The geological record from the area is important in the reconstruction of the maximum ice-sheet extent, dynamics and timing around Svalbard, as the northwestern part of the Eurasian Ice Sheet (e.g. Mangerud et al., 1998; Spielhagen et al., 2004; Svendsen et al., 2004; Winkelmann et al., 2008), and may also contain clues on the development or otherwise of an Arctic Ocean ice shelf at some point in the Quaternary (e.g. Mercer, 1970; Hughes et al., 1977; Grosswald and Hughes, 1999; Polyak et al., 2001; Jakobsson et al., in press).

In this paper, we present new, high-resolution geophysical evidence on the seafloor morphology and acoustic stratigraphy of the Yermak Plateau and northern Svalbard margin between $79^{\circ} 20^{\prime}$ and $81^{\circ} 30^{\prime} \mathrm{N}$ and $5^{\circ}$ and $22^{\circ} \mathrm{E}$ (Figs. $1 \mathrm{~b}$ and 2 ). Geophysical datasets 


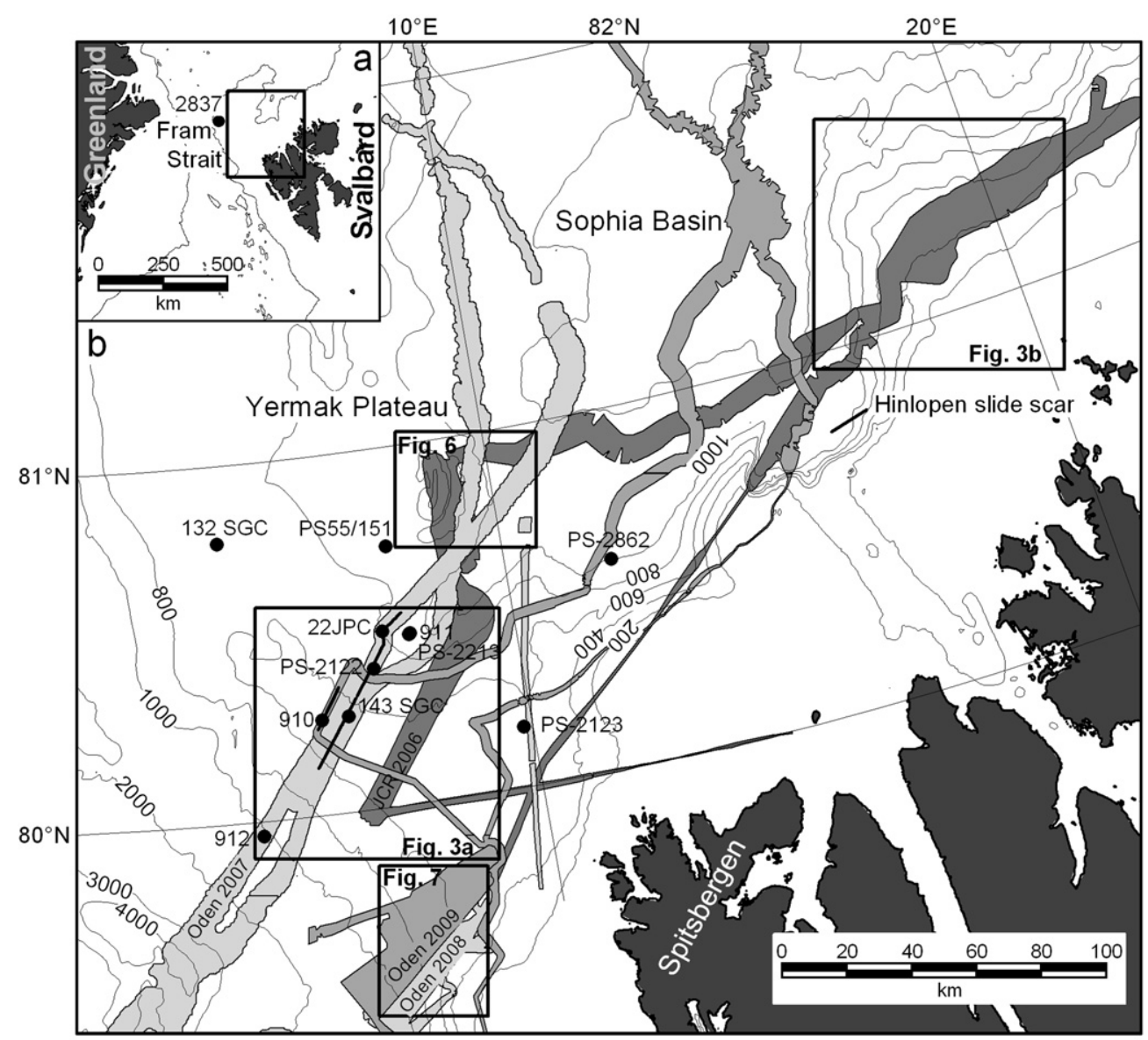

Fig. 1. (a) Overview map showing the location of the Yermak Plateau and northern Svalbard margin study area within the Arctic Ocean, to the east of Fram Strait. (b) Detailed map of the study area. Black dots are core sites. Coverage of multibeam swath-bathymetric data included in this study is shown with different shades of grey corresponding to different cruises: light grey =I/B Oden 2007; medium dark grey =I/B Oden 2008/2009; dark grey=I/B Oden 2009; very dark grey = RRS James Clark Ross 2006. Black boxes indicate the coverage of detailed swath imagery shown in Figs. 3, 6 and 7. Bathymetric contours are derived from a grid compiled by updating Version 2.0 of the International Bathymetric Chart of the Arctic Ocean (IBCAO) (Jakobsson et al., 2008b) together with the multibeam data included in this study.

are derived from multibeam bathymetry and sub-bottom acoustic profiling. In addition, the stratigraphy of Ocean Drilling Program (ODP) Leg 151 material and other short cores from the Yermak Plateau are re-examined in the context of our detailed geophysical data. We then discuss the implications of this new evidence on icesheet and iceberg grounding for the glacial history and past

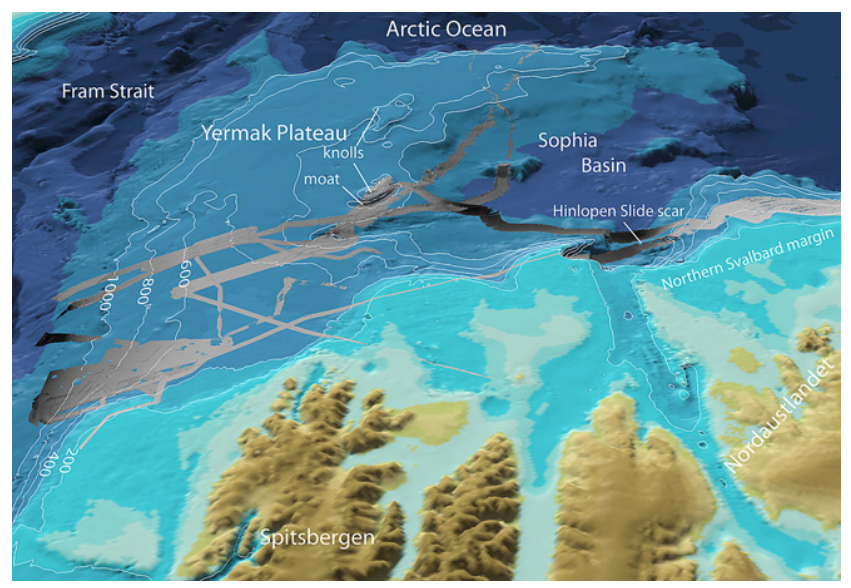

Fig. 2. Three-dimensional visualisation of the Yermak Plateau and northern Svalbard margin, viewed from the south (darker colours represent deeper water). Swathbathymetric data coverage is indicated in grey. Bathymetric contours ( $\mathrm{m}$ ) are shown for $200,400,600,800$ and $1000 \mathrm{~m}$. dynamics of the Eurasian Ice Sheet. Evidence from the whole Arctic Basin margin for a major Arctic Ocean ice shelf in Marine Isotope Stage (MIS) 6 is given in a separate paper in this volume (Jakobsson et al., in press).

\section{Methods}

The geophysical datasets used in this study were acquired from the Swedish icebreaker Oden and the British ice-strengthened research vessel RRS James Clark Ross, both equipped with hullmounted Kongsberg $12 \mathrm{kHz}$ EM120 $1^{\circ} \times 1^{\circ}$ multibeam bathymetry systems and sub-bottom profilers. The Oden sub-bottom profiler is a SBP $1203^{\circ} \times 3^{\circ}$ chirp sonar integrated with the multibeam. RRS James Clark Ross has a TOPAS PS 18 parametric system. The SPB 120 operates in the frequency range of $3-7 \mathrm{kHz}$ and the TOPAS has the capability of generating secondary frequencies in the range of $0.5-$ $5 \mathrm{kHz}$. Ship navigation data were all acquired using differential GPS and both ships were equipped with a Seatex Seapath 200 unit integrating navigation, heading and attitude information to the multibeam system. Data were acquired during cruise JR142 of the RRS James Clark Ross in September 2006 and during the Lomonosov Ridge off Greenland (LOMROG) expedition in August to September 2007 with Oden (Jakobsson et al., 2008a). The Oden multibeam was upgraded to Kongsberg's EM122 in 2008 and swath bathymetry was also collected with this system from the southeastern corner of the Yermak Plateau during short cruises in 2008 and 2009 (Fig. 1). 
The multibeam data were processed using Caris HIPS, Fledermaus and MB Systems through filtering and the removal of anomalous pings. They were gridded at cell sizes of $15-30 \mathrm{~m}$, depending on water depth. The multibeam data from all these cruises were merged using Fledermaus and brought into Intergraph's GIS software Geomedia Professional for analysis and map generation.

The spatial coverage of these swath-bathymetric datasets is shown in Figs. 1 and 2. North of about $81^{\circ} \mathrm{N}$ on the Yermak Plateau, the quality of the geophysical data is poor. This is because Oden had entered Arctic pack ice at this point and was breaking thick sea-ice, which has degraded the data quality.

The parameters used for correlation between Yermak Plateau cores, discussed later in this paper, were retrieved from publicdomain archives (e.g. ODP, Pangea). Bulk density and magnetic susceptibility were used, together with published age models, to construct an integrated stratigraphy.

\section{Submarine landforms from swath bathymetry}

The general topography of the seafloor northwest and north of Svalbard is illustrated in a three-dimensional visualisation shown in Fig. 2. This is derived from the International Bathymetric Chart of the Arctic Ocean (IBCAO; Jakobsson et al., 2008b), and other bathymetric datasets from the area (e.g. Winkelmann et al., 2008). The Yermak Plateau is a 'hook-shaped' and relatively flat area lying mainly between $600 \mathrm{~m}$ and $1000 \mathrm{~m}$ below the modern sea-surface. A southerly ridge crest and two knolls further north on the Plateau are less than $600 \mathrm{~m}$ in water depth (Fig. 2). The Yermak Plateau is separated from the northern Svalbard margin to the east by the huge Sophia Basin, whose morphology has been shaped largely by the $2400 \mathrm{~km}^{3}$ Hinlopen/Yermak Slide which affected an area of over $10,000 \mathrm{~km}^{2}$. The slide occurred mainly in MIS 3, with some subsequent activity (e.g. Vanneste et al., 2006; Winkelmann et al., 2006; Winkelmann and Stein, 2007).

Our merged swath-bathymetric data cover a total area of $>12,000 \mathrm{~km}^{2}$, imaging the Yermak Plateau to the northwest of Svalbard and the northern Svalbard margin (Figs. 1b and 2). Vogt et al. (1994) described much of the Yermak Plateau based on sidescan sonar imagery, but high-resolution swath-bathymetry was unavailable at that time. The seafloor in these areas northwest and north of Svalbard contains four types of submarine feature. Each will now be described and interpreted, and illustrated in Figs. 3-7.

\subsection{Lineations - streamlined subglacial landforms}

\subsubsection{Description}

Subdued linear features, up to at least $20 \mathrm{~km}$ in length are found on the ridge on the southern side of the Yermak Plateau in water depths generally shallower than $600 \mathrm{~m}$ (Figs. 3a and 4). On both swath transects of the ridge, these linear and occasionally curvilinear features exceed the extent of our datasets, so their total length is unknown. In general, the westerly set of lineations has an orientation of SSE-NNW ( $168^{\circ}$ to $\left.348^{\circ}\right)$ (Fig. 4a). The easterly set is orientated about $3-4^{\circ}$ clockwise with respect to the westerly set, has wider range of about $10^{\circ}$ and shows some evidence of bifurcation (Fig. 4b). On swath imagery, the features appear to have subdued and non-erosive edges, and are formed within acoustically transparent sedimentary material (as illustrated later in sub-bottom profiler records of Fig. 10). The mean crest to trough height of the features is about $10 \mathrm{~m}$ in Fig. $4 \mathrm{a}$, and $7 \mathrm{~m}$ for Fig. $4 \mathrm{~b}$, with average wavelengths of approximately $520 \mathrm{~m}$ and $480 \mathrm{~m}$, respectively. Few similar features are found elsewhere on our bathymetric data from the Yermak Plateau, except for a small area at about $80^{\circ} \mathrm{N} 10^{\circ} \mathrm{E}$. None is observed on imagery of the northern Svalbard margin (Fig. 3b).
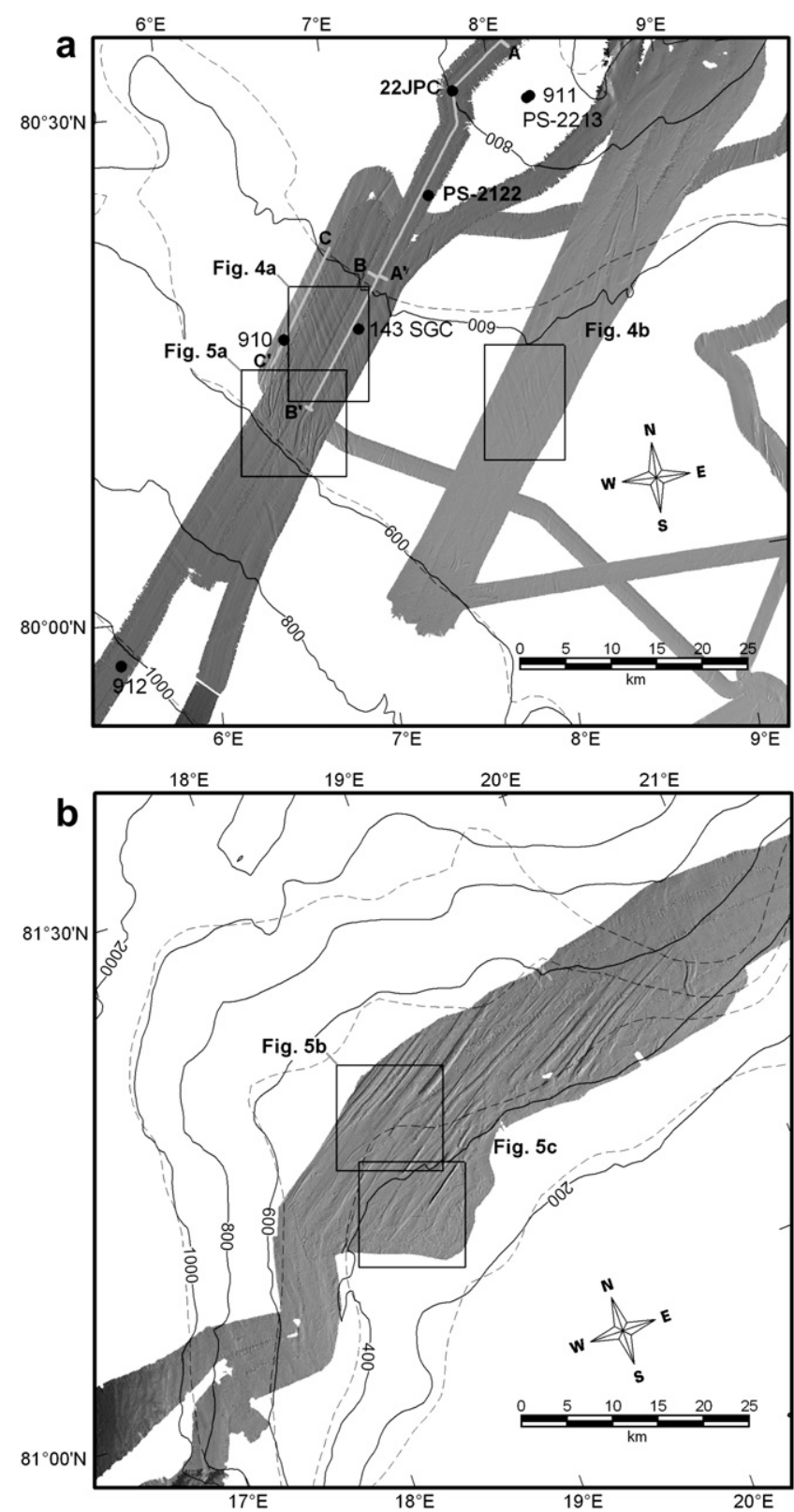

Fig. 3. Swath-bathymetric imagery from two parts of the study area (located in Fig. 1) (a) The crest and flanks of the southern Yermak Plateau. The black boxes denote detailed swath-bathymetric imagery shown in Figs. 4 and 5a. Note that the acoustic profiles labelled $A-A^{\prime}, B-B^{\prime}$ and $C-C^{\prime}$ are found in Figs. 9-11, respectively. (B) The northern Svalbard margin. The black boxes denote detailed swath-bathymetric imagery shown in Fig. 5b and c. Dashed contour lines are derived from IBCAO data (Jakobsson et al., 2008b), and solid contours are updated by the swath bathymetry from this paper.

\subsubsection{Interpretation}

The lineations are of similar morphology as linear to curvilinear submarine landforms described from formerly ice-sheet covered continental shelves around both Antarctica and the Norwegian margin (e.g. Canals et al., 2000; Ó Cofaigh et al., 2002; Ottesen et al., 2005; Dowdeswell et al., 2008). They are similar to mega-scale glacial lineations (MSGL) and other streamlined subglacial landforms (Clark, 1993), which are produced in deforming sediments at the base of past and present ice sheets (Dowdeswell et al., 2004; Schoof and Clarke, 2008; King et al., 2009). The occurrence of these sedimentary lineations on the 

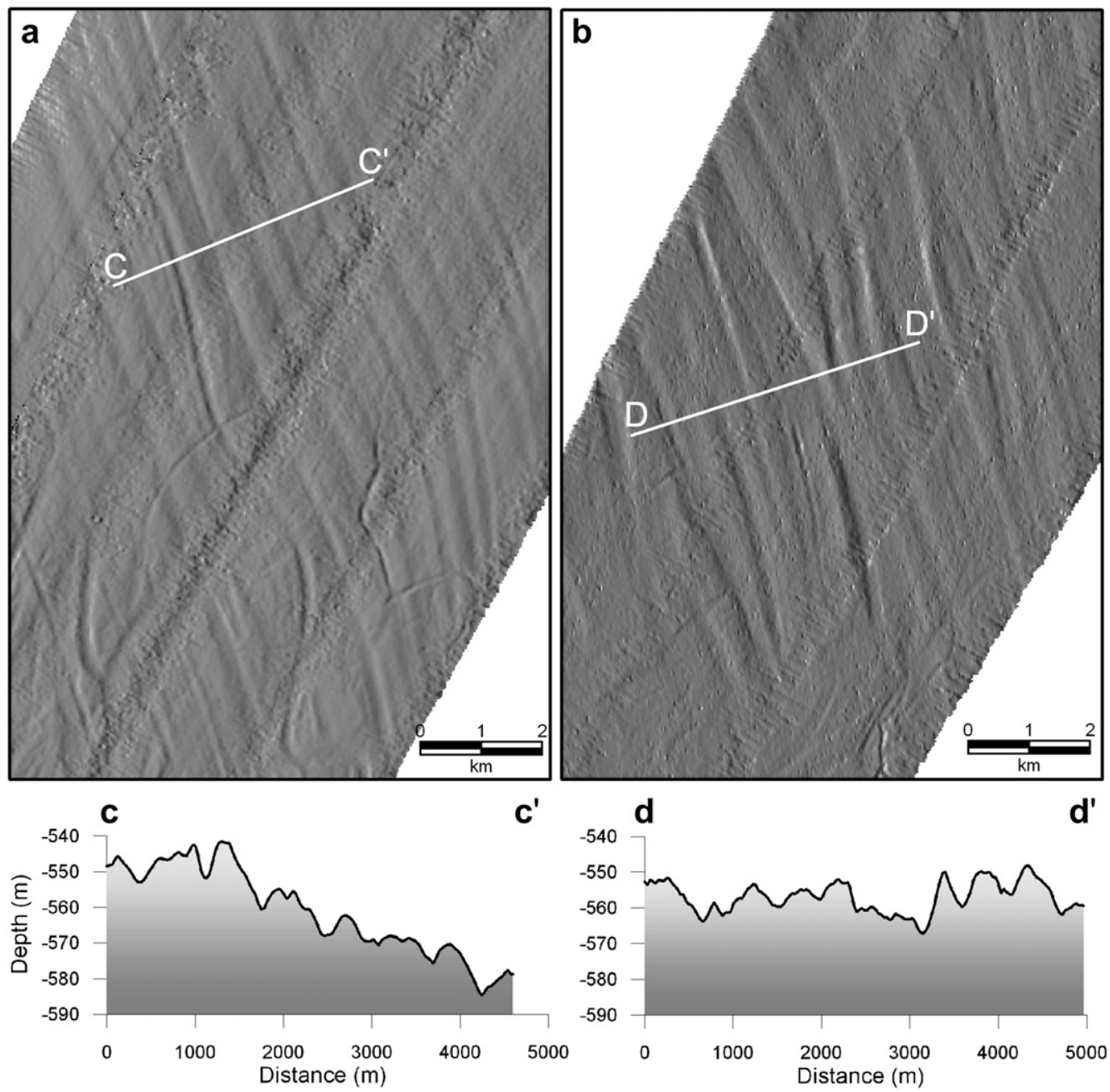

Fig. 4. Linear seafloor features on the Yermak Plateau. (a) Lineations and cross-cutting iceberg ploughmarks on the western swath transect across the crest of the Plateau. (b) Lineations on the eastern swath transet. Both images are located in Fig. 3a. Seafloor depth profiles along the indicated paths $C-\mathrm{C}^{\prime}$ and $\mathrm{D}-\mathrm{D}^{\prime}$ are shown below each respective image.

Yermak Plateau suggests that a coherent ice mass may have flowed across the plateau from SSE to NNW or vice versa (Fig. 4).

Interestingly, the ridge area on the southern Yermak Plateau was described by Vogt et al. (1994) as one of weak backscatter on sidescan sonar records. They suggested that an ice shelf was probably grounded on this part of the Plateau, removing earlier iceberg ploughmarks and homogenising the seafloor sediments to give the low backscatter. They noted that 'fluting' by grounded ice would provide conclusive evidence for grounded ice as opposed to bottom currents. Such evidence is now presented in Fig. 4, and we discuss the possibility of ice-sheet, ice-shelf or iceberg grounding on the Yermak Plateau in more detail later in this paper. The broader perspective of an Arctic Ocean ice shelf is presented in Jakobsson et al., in press.

\subsection{Large- and small-scale curvilinear features - iceberg ploughmarks}

\subsubsection{Description}

Large numbers of curvilineaer features are present on the seafloor of the Yermak Plateau and northern Svalbard margin, especially at water depths of less than $800 \mathrm{~m}$ (Figs. 3 and 5). The features are of two types. The first are large quasi-linear to curvilinear features of up to $6 \mathrm{~km}$ in length, $600 \mathrm{~m}$ wide and $20 \mathrm{~m}$ deep on the Yermak Plateau (Fig. 5a). On the northern Svalbard margin, similar features are up to $23 \mathrm{~km}$ in length, $1 \mathrm{~km}$ wide and over $80 \mathrm{~m}$ deep (Fig. 5b). These features are usually less regular and also often deeper than the linear features reported in the previous section. In both areas, the curvilinear features are clustered within a fairly well-defined band of water depths (about 560-600 $\mathrm{m}$ for the southwest side of the Yermak Plateau and $400-600 \mathrm{~m}$ for the northern Svalbard margin), both above and below which few are present. At first sight, many features appear linear, but detailed inspection shows that some are slightly curvilinear, whereas others are composed of several straight sections interspersed with directional shifts of sometimes just a few degrees. In addition, individual linear features often appear to form part of a coherent pattern, reminiscent of the teeth of a comb moving through a deforming medium. These linked sets of features are up to $7 \mathrm{~km}$ wide (Figs. 3b and $5 b$ ). The appearance on swath imagery is of features with sharply defined lateral margins. The terminations at the ends of features can be open or closed, with those at the deep-water end usually being open (Fig. 5).

The second type of feature is smaller and highly irregular in direction relative to its larger counterpart (Fig. 5c). Direction changes of $90^{\circ}$ or more are often observed. The length of individual segments is generally less than $1 \mathrm{~km}$, although several segments often appear to be continuations of one-another. Feature width and 

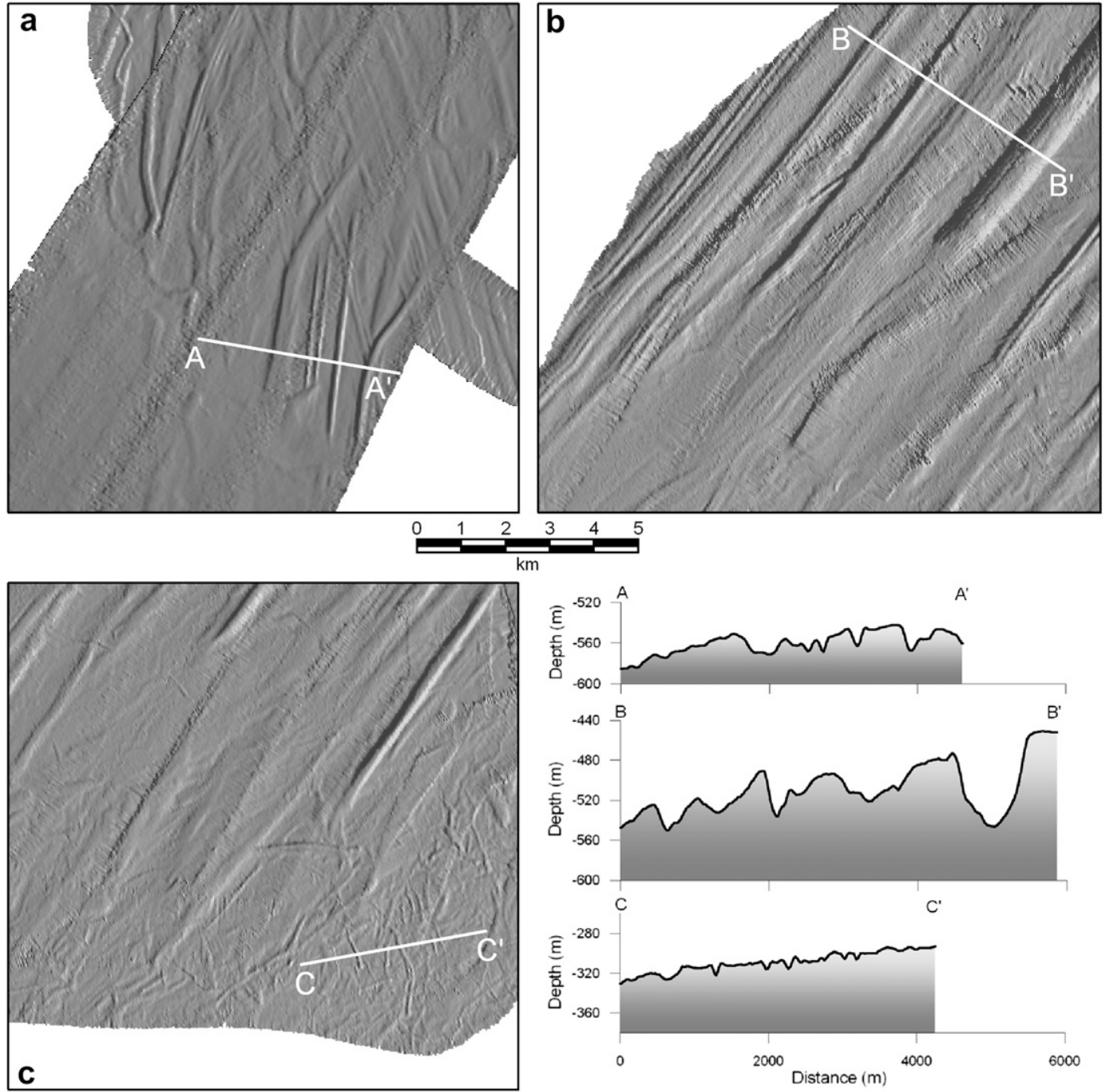

Fig. 5. Examples of large and small curvilinear features, interpreted as iceberg ploughmarks, on the Yermak Plateau and northern Svalbard margin. (a) Large ploughmarks on the southern flank of the Yermak Plateau (located in Fig. 3a). (b) Large ploughmarks on the northern Svalbard margin (located in Fig. 3b). (c) Small, irregular ploughmarks on the northern Svalbard margin, with larger ploughmarks in deeper water to the north (located in Fig. 3b). Bathymetric profiles across each set of ploughmarks are shown.

depth is also much less than the larger forms described above. Widths are generally less than $100 \mathrm{~m}$ and depth is usually less than $10 \mathrm{~m}$ (Fig. 5). In our study area, the smaller and less regular features are best developed on the northern Svalbard margin, in shallower water than the larger features; typically at less than $400 \mathrm{~m}$. Like their larger counterparts, these features appear erosive on swath imagery, and can be seen to cross-cut and disturb one another. They also cross-cut some of the larger features, where both sets of forms are present, implying a younger relative age.

\subsubsection{Interpretation}

Both types of curvilinear feature shown in Fig. 5 are interpreted to have formed as a result of ploughing of the seafloor by iceberg keels. Similar submarine landforms have been observed on both Arctic and Antarctic continental shelves, where unlithified sediments at depths less than about $500 \mathrm{~m}$ have often been reworked by the action of iceberg keels (e.g. Woodworth-Lynas et al., 1985; Barnes and Lien, 1988; Dowdeswell et al., 1993; Syvitski et al., 2001; Jakobsson et al., 2005). Where several large ploughmarks are located parallel to one another for distances of many kilometres, we suggest that they are either produced by multiple keels of a single megaberg or by the keels of several icebergs that are trapped together within multi-year sea ice which maintains their relative positions (Kristoffersen et al., 2004). The deepest ploughmarks on the northern Svalbard margin, at almost $100 \mathrm{~m}$ from the general level of the seafloor to their base, are some of the largest ever observed (Fig. 5b) (Kuijpers et al., 2008).

The orientation of large ploughmarks on the northern Svalbard margin is predominantly NNE-SSW (Fig. 5b). Likely sources for these large icebergs are the Franz Victoria and St. Anna ice streams (Vogt et al., 1994; Dowdeswell, 1995; Dowdeswell and Siegert, 1999; Kleiber et al., 2000; Knies et al., 2001), which drained northward from the Barents Sea area of a past Eurasian Ice Sheet (Dowdeswell et al., 2010). The icebergs probably drifted westward, perhaps trapped within multi-year sea ice to account for their uniform orientation.

\subsection{Moat - current overflow channel}

\subsubsection{Description}

A $23 \mathrm{~km}$-long moat-like feature is a very distinctive landform within the swath mosaic, centred at about $80^{\circ} 50^{\prime} \mathrm{N} 9^{\circ} 20^{\prime} \mathrm{E}$ 


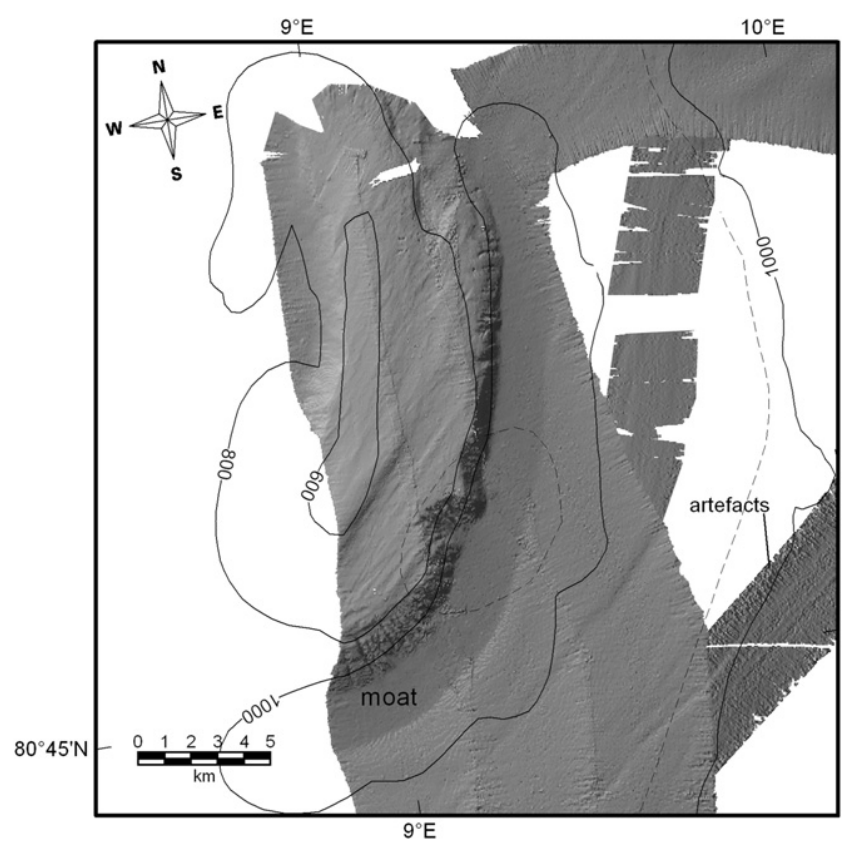

Fig. 6. Flat-floored moat with steep margins to the east of a relatively flat-topped knoll ('guyot' of Vogt et al., 1994) on the Yermak Plateau. The image is located in Fig. 1 and visualised as part of Fig. 2. Dashed contour lines are derived from IBCAO data (Jakobsson et al., 2008b), and solid contours are updated by the swath bathymetry from this paper.

(Fig. 6). The moat trends west-east at its southern end and curves through $90^{\circ}$ to trend south-north at its northward limit. We do not image the western and northern terminations of the moat, and the length given above is, therefore, a minimum value.

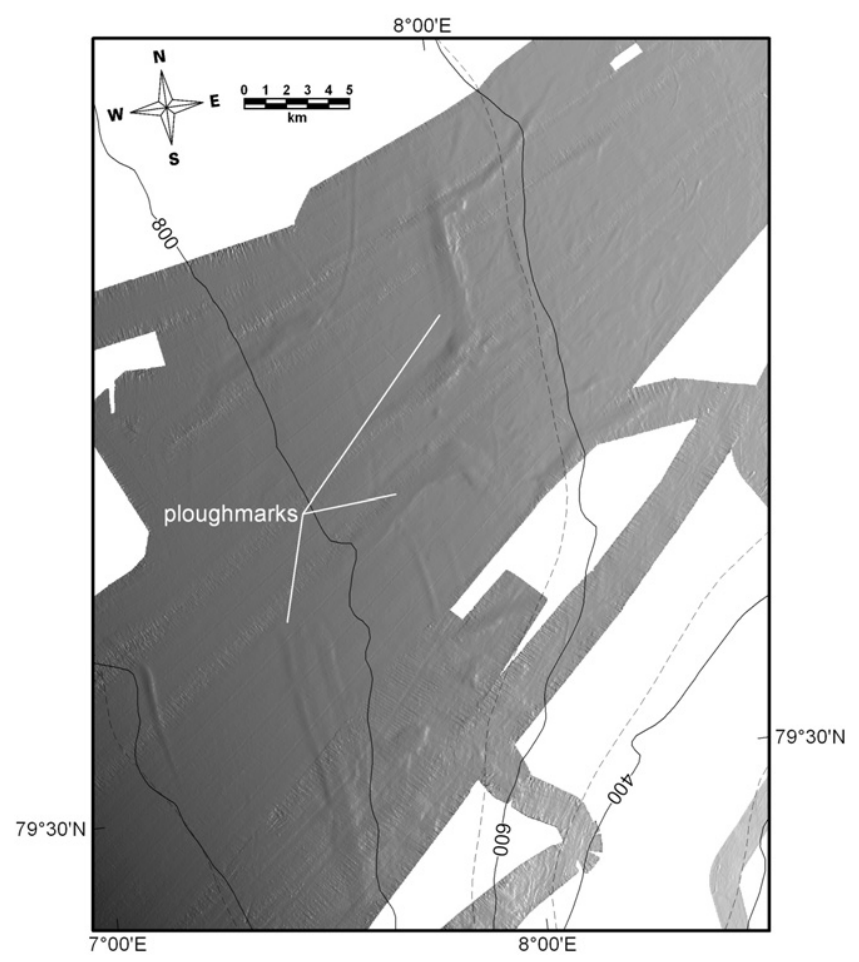

Fig. 7. Swath imagery of a relatively undisturbed area of the seafloor on the southern flank of the Yermak Plateau (located in Fig. 1). Note the subdued iceberg ploughmarks at depths down to almost $1000 \mathrm{~m}$. Dashed contour lines are derived from IBCAO data (Jakobsson et al., 2008b), and solid contours are updated by the swath bathymetry from this paper.
The moat is about $2 \mathrm{~km}$ wide has a flat and featureless floor, at the resolution of our swath bathymetric data, with a depth of about $1200 \mathrm{~m}$. A $400 \mathrm{~m}$-high slope of about $25^{\circ}$ defines the north/west margin of the moat (Fig. 6). This slope has a rough appearance on swath imagery, and is dissected by a number of gullies and one larger amphitheatre-like indentation about $1.5 \mathrm{~km}$ across (Fig. 6). The south/east side of the moat is less well-defined, with a much gentler slope angle of about $8^{\circ}$. Beyond this edge of the moat, the seafloor is relatively flat and featureless.

A relatively flat-topped area of almost $200 \mathrm{~km}^{2}$ is present beyond the north-west edge of the moat. Our swath-bathymetric data show that this area reaches a minimum depth of $525 \mathrm{~m}$. Detailed inspection shows subtle linear features trending NE-SW, especially on the southeastern flank (Fig. 6).

\subsubsection{Interpretation}

Vogt et al. (1994), using side-scan sonar and $3.5 \mathrm{kHz}$ profiles from the Yermak Plateau, first described this feature and interpreted it as a current-produced moat surrounding an iceberg gouged guyot' that rises about $100-300 \mathrm{~m}$ above the moat floor. Unfortunately, no bedforms can be identified on the moat floor, and sub-bottom profiler data do not reveal any additional information regarding the processes forming the moat. However, the gross morphology of the moat is analogous to overflow channels from the Norwegian Sea into the North Atlantic Ocean (e.g. Kuijpers et al., 1998, 2002), and we therefore interpret the feature as a currentrelated overflow channel.

The current responsible for the formation of the moat has been inferred to be the northeast-flowing West Spitsbergen Current (Eiken and Hinz, 1993; Vogt et al., 1994). This is consistent with the direction of water flow around northwestern Svalbard today.

\subsection{Largely featureless seafloor - hemipelagic deposits}

\subsubsection{Description}

At water depths beyond $800 \mathrm{~m}$, the range of all but the deepest-keeled icebergs, the seafloor is generally featureless at the resolution of our swath imagery (Fig. 7). The same is largely the case where the three types of landform described above are absent at shallower depths. Occasionally, particularly deep-keeled icebergs have produced linear erosion features at greater depths (Fig. 7).

\subsubsection{Interpretation}

The relatively flat and featureless areas of seafloor on the Yermak Plateau are inferred to be a product of hemipelagic sedimentation. The presence of an acoustically stratified stratigraphy in these areas supports this interpretation.

\subsection{Distribution of landform types on the Yermak Plateau and northwest of Svalbard}

The geographical distribution of submarine landforms in our swath-bathymetric data from the Yermak Plateau and northern Svalbard margin, described and interpreted above, is plotted in Fig. 8. Evidence from two other datasets is included in this figure. First, seafloor landforms observed from side-scan sonar records by Vogt et al. (1994) are shown where they occur outside the areas of our own swath-bathymetric coverage. Their observations of seafloor lineations east of those that we map provide an important link between our data and those from the Svalbard shelf. Secondly, the pattern of submarine landforms on the continental shelf of northwesternmost Svalbard is shown (Ottesen and Dowdeswell, 

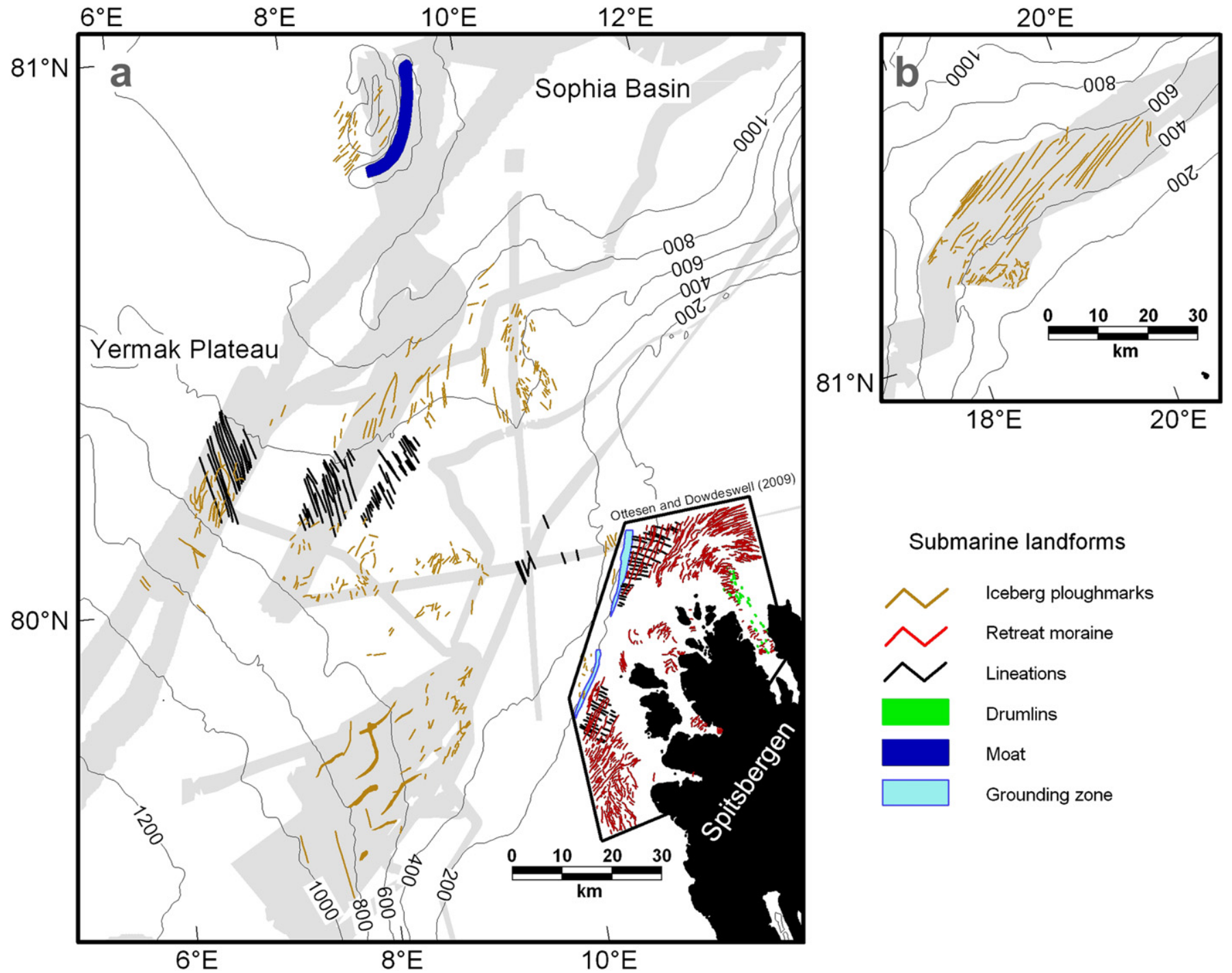

Fig. 8. (a) Map of the distribution of submarine landform types on the Yermak Plateau, adjacent shelf and northern Svalbard margin. The area shaded grey represents our swath bathymetric coverage (Fig. 1). Those landforms outside the grey mask are from Vogt et al. (1994). Also included are features identified by Ottesen and Dowdeswell (2009) from the shelf of northwesternmost Spitsbergen. (b) Map of landform types on the northern Svalbard margin. Only iceberg ploughmarks were observed on swath imagery.

2009), as these data relate our Yermak Plateau observations to the behaviour of ice on Svalbard itself at and since the Late Weichselian maximum. The ice-sheet grounding-zone described by Ottesen and Dowdeswell (2009) implies that Late Weichselian ice did not flow onto the Yermak Plateau from the adjacent continental shelf (Fig. 8).

Lineations, similar to MSGL and other streamlined subglacial landforms, are mapped on the ridge crest of the southern Yermak Plateau (trending SSE-NNW) and are also found, importantly with a orientation different by about $45^{\circ}$, on the shelf edge northwest of Spitsbergen (trending ESE-WNW) (Fig. 8a). Iceberg ploughmarks are located on the flanks of the Yermak Plateau, on the 'guyot' in the north of our study area (Fig. 8a), and on the outer, deepening part of the northern Svalbard margin (Fig. 8b). A single moat, interpreted as a current overflow channel, is also found on the Plateau, in an otherwise relatively flat and featureless seafloor terrain. The significance of these seafloor landforms is discussed further below, in the context of the acoustic stratigraphy and chronology of Quaternary events on the Yermak Plateau.

\section{Acoustic stratigraphy of the Yermak Plateau}

\subsection{Description}

The shallow stratigraphy of the Yermak Plateau shows three acoustic units defined from our sub-bottom profiler data. The first unit, Unit A, has well-developed stratification (Fig. 9 and 10), that is often draped over a strong and undulating internal reflector (R1). This internal reflector appears to be of similar form to the seafloor morphology shown in Fig. 11. The acoustically stratified unit thickens down-slope on the north-eastern side of the Yermak Plateau crest, from $\sim 5 \mathrm{~ms}$ around core site 143-SGC to nearly $25 \mathrm{~ms}$ at core site 22-JPC (Figs. 9 and 10).

A second acoustic unit, Unit B, is characterised by an undulating upper surface at or close to the present seafloor and little acoustic penetration (Figs. 10 and 11). This unit is found mainly at water depths less than about $580 \mathrm{~m}$. Its undulating surface cross-section corresponds to the sea-floor lineations illustrated in plan-view in Fig. 4. There is a hint that minor sediment infilling may have taken place in some of the 'troughs' making up the undulations (Fig. 11). 


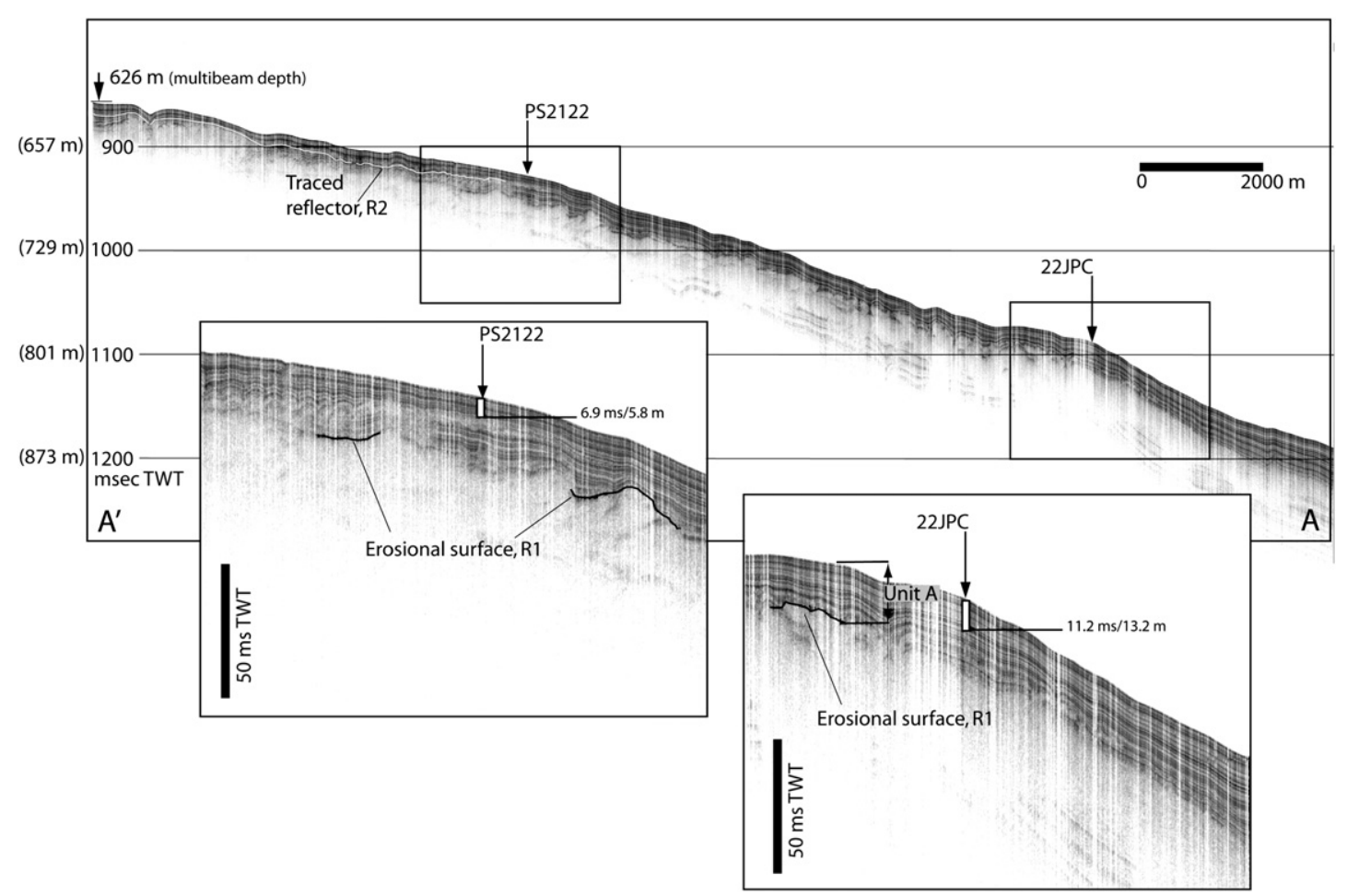

Fig. 9. Chirp sonar sub-bottom profile from the north-eastern flank of the crest of the Yermak Plateau. Located as A and $A^{\prime}$ in Fig. 3a. The acoustic stratigraphy around two core sites is enlarged. Core site HLY0503-22-JPC is located directly on the profile while PS2122 is located $\sim 800 \mathrm{~m}$ to the southeast and has been projected onto the profile. The conversion from core length in metres (recovered sediments) to two-way travel time uses the relationship calculated for ODP Site 911 from analysed physical properties. Site 911 is located on the north-eastern flank of the Yermak Plateau approximately $8.6 \mathrm{~km}$ east of HLY0503-22-JPC.

A third unit is an acoustically transparent facies, Unit C, observed mainly on the southwestern side of the Plateau crest (Fig. 10). This unit typically comprises several stacked transparent acoustic subunits, separated by internal reflectors of varying lateral continuity (Fig. 10).

\subsection{Interpretation}

The undulating seafloor present on acoustic records above about $580 \mathrm{~m}$ is interpreted as a series of ice-produced lineations, given its spatial concurrence with the linear features observed on swath bathymetry and interpreted in this way. The low penetration of Unit B probably arose from the relatively high acoustic impedance of diamictic or glacially-disturbed sediments. A prominent reflector (R2) located just deeper in the acoustic stratigraphy than the penetration of core 143-SGC is traced in Figs. 9 and 10. It is evident that a $20 \mathrm{~ms}$ difference in the thickness of the acoustically stratified unit is present. From a water depth of about $660 \mathrm{~m}$, the sediment thickness between the traced reflector (R2) and the erosional surface beneath (R1) increases considerably

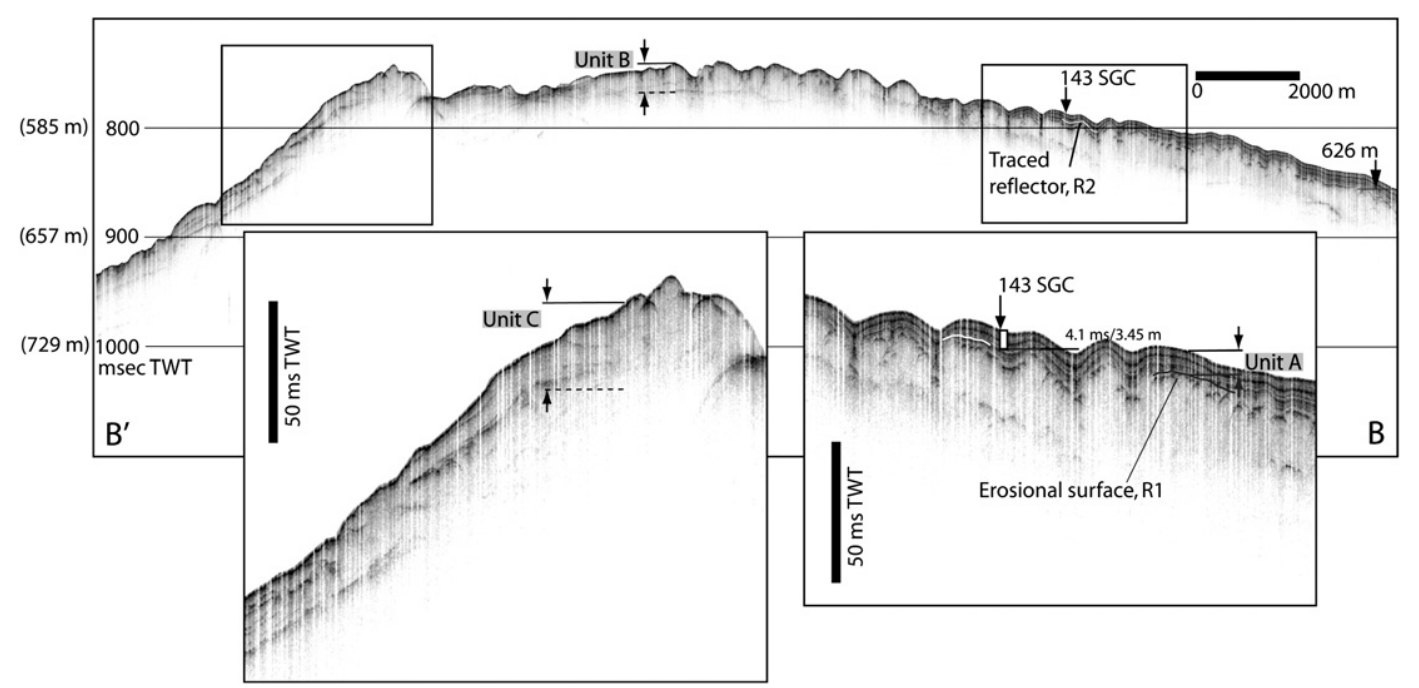

Fig. 10. Chirp sonar sub-bottom profile across the crest of the Yermak Plateau. Located as B and $B^{\prime}$ in Fig. 3a. The acoustic stratigraphy in two areas, one including core 143-SGC, is enlarged. 


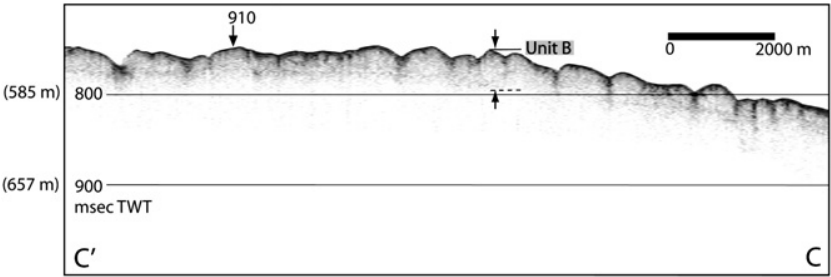

Fig. 11. Chirp sonar sub-bottom profile from the crest of the Yermak Plateau, west of Fig. 10. Located as $C$ and $C^{\prime}$ in Fig. 3a. Note the lack of acoustic penetration.

(Fig. 9). The most obvious explanation for this is that the Yermak Plateau has been eroded more than once and that the erosional surfaces merge on the shallow crest of the plateau; that is, there are two erosional surfaces that join to form a single surface on the shallower part of the plateau, while only the older surface extends deeper and is therefore draped by more acoustically stratified sediment. The ice-eroded features on the seafloor remained at the surface, presumably because currents removed subsequent sediments, but further downslope the acoustically stratified layer was able to accumulate and become thicker with depth (Figs. 9 and 10). The longer term reflection-seismic stratigraphy and architecture of the whole northern Svalbard margin is summarized in Geissler and Jokat (2004). All the core material we discuss falls within the uppermost reflection-seismic unit (Unit Y[ermak]P [lateau] 3) of Geissler and Jokat (2004), the lower boundary of which is over $2.5 \mathrm{Myr}$ old.

The sub-bottom profiles also show a generally less disturbed stratigraphy on the north-eastern side of the Yermak Plateau crest compared to the southwestern side. Here, stacked features of transparent acoustic character (Acoustic Unit C), interpreted as debris flows, can be distinguished. This indicates that reworking of the stratigraphy has occurred (Fig. 10).

\section{Litho/biostratigraphy and age of sediments on the Yermak Plateau}

\subsection{ODP cores}

Several deep boreholes from Ocean Drilling Program (ODP) Leg 151 (Thiede et al., 1996), together with a number of short piston and gravity cores collected from the Yermak Plateau and adjacent ocean, provide chronological control on the acoustic stratigraphy outlined above (Fig. 12). Three sites (910, 911 and 912) were drilled on Leg 151 (Thiede et al., 1996), forming an $80 \mathrm{~km}$ transect across the crest of the southern Yermak Plateau (Fig. 1). Over $500 \mathrm{~m}$ of Pliocene and younger sediments were penetrated at sites 910 and 911, and $209 \mathrm{~m}$ of similarly aged sediments at Site 912 . Calcareous nannofossil and foraminiferal biostratigraphy placed the former base of the Pleistocene (i.e. $1.88 \mathrm{Myr}$ ) between 60 and $76 \mathrm{~m}$ below the seafloor (bsf) at Site 910, 222-228 m bsf at Site 911 and $132 \mathrm{~m}$ bsf at Site 912 (Sato and Kameo, 1996; Spiegler, 1996). These translate into relatively high Pleistocene linear sedimentation rates, ranging from 33-42 $\mathrm{m} \mathrm{Myr}^{-1}$ at Site 910 to $126 \mathrm{~m} \mathrm{Myr}^{-1}$ at Site 911.

One of the initial findings of Leg 151 was the recognition of a heavily overconsolidated interval extending between 19 and $95 \mathrm{~m}$ bsf at Site 910 (Thiede et al., 1996). This was subsequently attributed to the grounding of a marine-based ice sheet and dated, using a planktic foraminiferal $\delta^{18} \mathrm{O}$ stratigraphy, to at or near the MIS 16/17 boundary (Flower, 1997) with an age of $676 \mathrm{kyr}$ (Lisiecki and Raymo, 2005). A more recent age model for Hole 910A, incorporating additional palaeomagnetic measurements and $\delta^{18} \mathrm{O}$ and $\delta^{13} \mathrm{C}$ analyses of planktic and benthic foraminifera, indicates that the youngest sediments on top of the overconsolidated zone were deposited after the
MIS 19/20 boundary at $790 \mathrm{kyr}$ (Knies et al., 2007). While both the original (Flower, 1997) and revised chronology (Knies et al., 2007, 2009) rely mainly on calibration of planktic $\delta^{18} \mathrm{O}$ variations with global type curves, they are each supported by the overall normal magnetic polarity of the upper $19.5 \mathrm{~m}$ bsf, and the occurrence of a key calcareous nannofossil datum, Pseudoemiliania lacunosa, which has a calibrated last occurrence in late MIS 12 (Thierstein et al., 1977). In Hole 910A, the last occurrence of $P$. lacunosa is at $9.7 \pm 0.75 \mathrm{~m}$ bsf (Sato and Kameo, 1996), about $10 \mathrm{~m}$ above the heavily overconsolidated interval. Analysis of multichannel seismic data collected on the Yermak Plateau identified a peneplained surface corresponding to the top of the overconsolidated unit at $20 \mathrm{~ms}$ TWT beneath the seafloor (Kristoffersen et al., 2004), and a depositional wedge located along the southeastern flank of the plateau extending down in parts to a water depth of $1000 \mathrm{~m}$. The evidence from sediment overconsolidation, implying ice-grounding at Site 910 at a water depth of greater than $550 \mathrm{~m}$, indicates that there was at least one early to mid-Pleistocene glacial period that resulted in a significant ice advance onto the continental margin northwest of Svalbard (e.g. Knies et al., 2009).

\subsection{Short cores}

A key question is whether the linear ice-produced bedforms mapped in Fig. 8 can be attributed to the early/mid-Pleistocene event discussed above, or are related to a more recent icegrounding episode? To address this we have integrated chronological and physical-property data from ODP site 911 and eight shorter cores collected from the region on several different expeditions (Fig. 1, Table 1). These cores range in water depth from 1049 to $560 \mathrm{~m}$, with three occurring within the depth interval and region containing subglacial lineations (143-SGC, PS2122, PS2123) (Fig. 1, Table 1 ).

Published age models for PS2122 and PS2123 indicate that both these cores extend back into MIS 5 (Vogt et al., 2001). Here we also show that down-hole variations in the physical properties of these cores (magnetic susceptibility and bulk density) are readily correlated. In fact, the correlation for these cores can be extended to include five additional shorter cores from the region (Fig. 12), and corroborated by independent high-resolution AMS ${ }^{14} \mathrm{C}$ dating from PS2837.

A feature common to all the short cores, and also preserved in the longer ODP Site 911 composite record and 22-JPC (Fig. 12), is a discrete interval characterised by low magnetic susceptibility and high bulk density that occurs near the base of MIS 2 . This feature is dated directly in PS2837 at 27.8 Cal. kyr $\left(23.83{ }^{14} \mathrm{C} \mathrm{kyr}\right.$ ) (Fig. 12) and is identified as Event 1 in PS2122 and PS2123 by Vogt et al. (2001). Sediments from this interval have a characteristic geochemical and mineralogical signature that points to a Jurassic/Cretaceous shale source. They are probably delivered by icebergs derived from the southern Barents Ice Sheet as it eroded the shales of Spitsbergenbanken (Vogt et al., 2001). The overall stratigraphic continuity of sediments, and simple correlation of these geographically separated cores using physical properties, suggests that there is a largely undisturbed drape of acoustically stratified sediments extending at least to the base of MIS 2 on the Yermak Plateau (Figs. 9 and 10). This requires a pre-Late Weichselian age for the imaged subglacial lineations.

Below MIS 2, less distinct variations in the physical properties of the cores make further definitive regional tie points more difficult to establish. The similar physical properties and published chronologies of cores PS2122 and PS2123 show that the undisturbed drape of acoustically stratified sediments extends back into MIS 5. Abundance relationships between the main taxonomic categories (Emiliania huxleyi, Gephyrocapsa spp.) of calcareous nannofossils also place the base of both 132-SGC and 143-SGC within MIS 5 

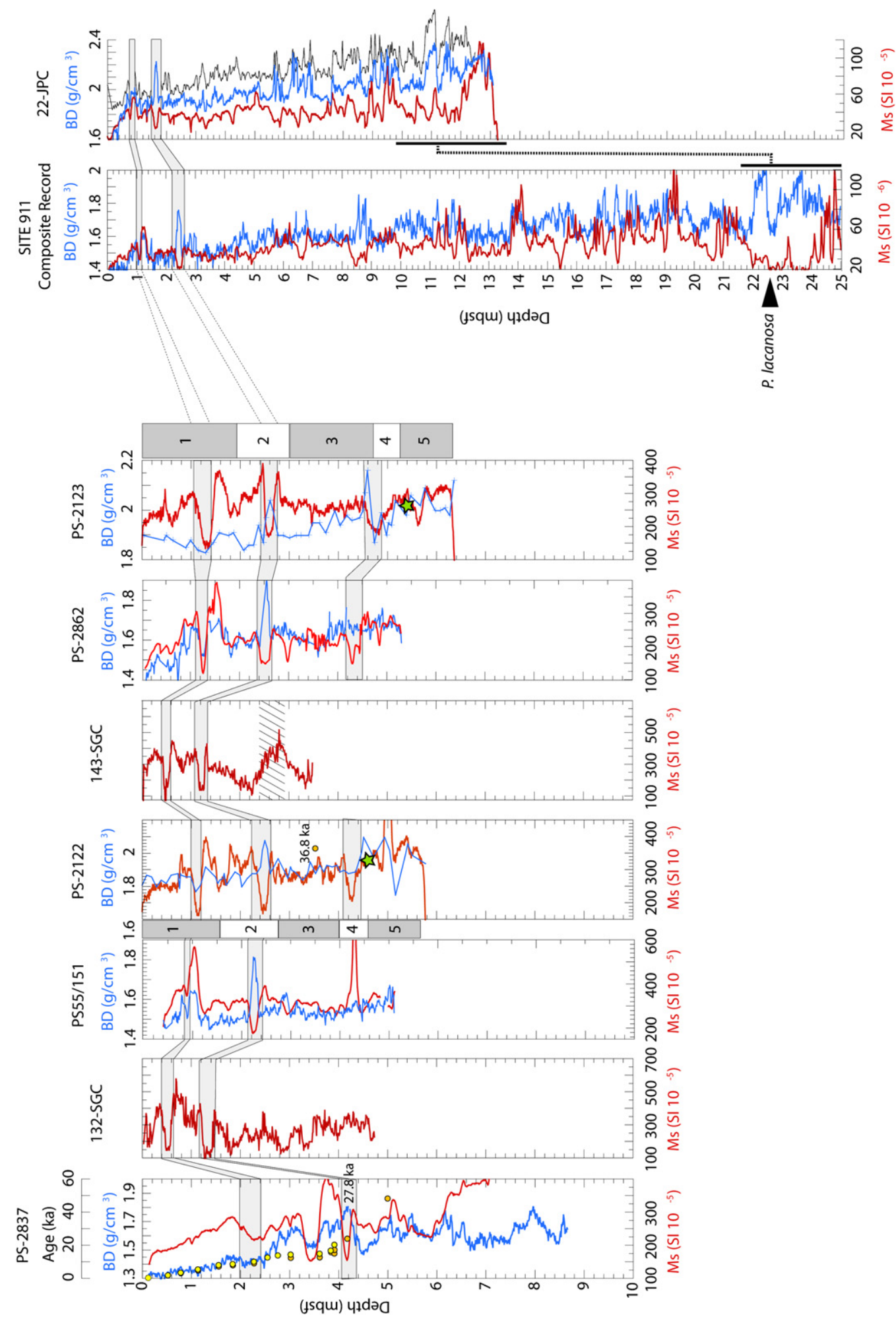

Fig. 12. Stratigraphic correlation of cores from the Yermak Plateau. Location of cores shown in Fig. 1 . BD = bulk density, Ms = magnetic susceptibility. Yellow circles denote position of AMS ${ }^{14} \mathrm{C}$ ages. Green stars mark occurrences of Bulimina aculeata, a benthic foraminifera used to identify late MIS 5 in Arctic Ocean sediments. Age models for PS2123 and PS2122 are shown alongside the physical properties for each core and are taken from Vogt et al. (2001). Grey bars highlight characteristic features used as regional tie points. A composite section from ODP Site 911 is shown on the metres composite depth scale (mcd) of Rack et al. (1996). The position of $P$. lacunosa can be correlated to the near-by piston core 22-JPC. For illustrative purposes the depth-migrated bulk density record from the composite section of Site 911 is shown in grey alongside the 22-JPC record using the tie points presented by Sellén et al. (2010). Cross-hatched zone in core 143-SGC is a sand layer of high magnetic susceptibility. Data for cores collected by the R.V. Polarstern (PS) are available through the following: Knies and Stein (1995). Sedimentology and geochemistry of core PS2122-2. doi:10.1594/PANGAEA.50008; Niessen, F. (2000), Physical properties of sediment core PS28375, doi:10.1594/PANGAEA.57656; Pirrung, M. (1999), Susceptibility of sediment core PS2837-5, doi:10.1594/PANGAEA.55785; Pirrung, M. (2000), Physical properties of sediment core PS55/151-2, doi:10.1594/PANGAEA.56895; Vogelsang, E. and Sarnthein, M. (2003), Age control of sediment core PS2837-5, doi:10.1594/PANGAEA.104834; Knies, J. (1994), Sedimentation am Kontinentalhang nordwestlich Spitzbergens. Der letzte Glazial/Interglazial-Zyklus, Diploma Thesis, Alfred Wegener Institute for Polar and Marine Research, Bremerhaven, 95 pp., http://store.pangaea.de/Publications/archive/DiplKnies.zip. 
Table 1

Details of short cores from the Yermak Plateau area used in this study (locations in Fig. 1; stratigraphy in Fig. 12).

\begin{tabular}{|c|c|c|c|c|c|c|c|c|}
\hline Core ID & Lat $\left(^{\circ}\right)$ & Long $\left({ }^{\circ}\right)$ & Depth (m bsl) & Length $(\mathrm{m})$ & Campaign & Bulk Density & Magnetic susc. & Age model \\
\hline PS2837 & 81.2333 & 2.3817 & 1023 & 8.7 & ARK-XIII/2 & $\mathrm{X}$ & $\mathrm{X}$ & $\mathrm{X}$ \\
\hline 132-SGC & 80.7833 & 5.1167 & 680 & 4.7 & YMER-80 & $\mathrm{n} / \mathrm{a}$ & $\mathrm{X}$ & $\mathrm{n} / \mathrm{a}$ \\
\hline PS55/151 & 80.7245 & 8.0220 & 971 & 5.2 & ARK-XV/2 & $\mathrm{X}$ & $\mathrm{X}$ & $\mathrm{n} / \mathrm{a}$ \\
\hline 22-JPC & 80.4898 & 7.7690 & 798 & 13.3 & HOTRAX & $\mathrm{x}$ & $\mathrm{X}$ & $\mathrm{n} / \mathrm{a}$ \\
\hline PS2122 & 80.3730 & 7.5072 & 702 & 5.8 & ARK-VIII/2 & $\mathrm{X}$ & $\mathrm{X}$ & $\mathrm{X}$ \\
\hline 143-SGC & 80.2667 & 7.0333 & 560 & 3.45 & YMER-80 & $\mathrm{n} / \mathrm{a}$ & $\mathrm{X}$ & $\mathrm{X}$ \\
\hline PS2862 & 80.5805 & 11.8118 & 1049 & 5.5 & ARK-XIII/2 & $\mathrm{X}$ & $\mathrm{X}$ & $\mathrm{n} / \mathrm{a}$ \\
\hline PS2123 & 80.1555 & 9.8478 & 573 & 6.5 & ARK-VIII/2 & $\mathrm{x}$ & $\mathrm{X}$ & $\mathrm{X}$ \\
\hline
\end{tabular}

(Jakobsson et al., in press). However, it should be noted that a clear break in the coherent regional stratigraphy occurs across a discrete unit in core 143-SGC, where a visually identified sand interval correlates to a high in magnetic susceptibility between 2.45 and $2.82 \mathrm{~m}$ bsf (Fig. 12). The calcareous nannofossil stratigraphy suggests that MIS 5.1 lies just below this unit $(300-305 \mathrm{~cm})$.

Poor acoustic penetration on the heavily lineated ridge crest of the Yermak Plateau prevents integration between core data and high-resolution sub-bottom data; for example at ODP Site 910 in Fig. 11. However, on sub-bottom profiles that extend across the flat crest and down the slopes of the Yermak Plateau, there is an easily recognised down-slope thickening sequence of acoustically stratified and seemingly undisturbed sediments. Where resolvable, the base of the acoustically stratified unit consists of large undulations and an abrupt reduction in acoustic penetration. The last occurrence of P. lacunosa at Site 911 (911A-3H-2-70 cm, $21.22 \mathrm{~m} \mathrm{bsf}$ ), and the equivalent stratigraphically correlated depth in 22-JPC (about $11.3 \mathrm{~m}$ bsf) (Fig. 12), can be calibrated with sub-bottom travel times through core-seismic integration using published relationships between depth and TWT from ODP Site 911 (Myhre et al., 1995). This shows that, at $800 \mathrm{~m}$ water depth, the base of the acoustically stratified unit is older than MIS 12 and is probably related to the mid-Pleistocene ice-grounding event identified on the ridge crest at ODP Site 910.

A similar exercise about $10 \mathrm{~km}$ upslope from 22-JPC illustrates that the acoustically stratified sequence extends well below the base of PS2122 (Fig. 10), which occurs within MIS 5 (Fig. 12). The shallowest water-depth core penetrating the acoustically stratified sequence is $143-\mathrm{SGC}$, a further $14 \mathrm{~km}$ upslope and close to the Plateau crest (Fig. 9). When migrated onto the sub-bottom profile, it is clear that the core base (MIS 5) does not penetrate to the bottom of the undisturbed acoustically stratified sediments (Fig. 10). It is likely that, assuming that there are two erosional surfaces that merge at shallower depths, the base of the acoustically stratified interval becomes younger upslope, with its depth beneath 22-JPC appearing much older than the depth beneath the shallower section found in the area of 143-SGC. It appears, therefore, that a younger ice-grounding event disturbed the sediments found above a water depth of about $700 \mathrm{~m}$ and, based on the chronology of 143-SGC, this occurred just prior to MIS 5 (Figs. 10 and 12).

These observations suggest that the ice-produced lineations on the ridge crest of the Yermak Plateau were not inherited from an early/mid-Pleistocene grounding event, but most likely occurred at or around MIS 6; that is, in Saalian time.

\section{Discussion}

\subsection{Evidence for ice-sheet grounding on the Yermak Plateau}

The observation of large-scale ice-produced lineations on the crest of the Yermak Plateau (Fig. 4), and a buried erosion surface of similar morphology on its flanks (Figs. 9 and 10), implies the presence of grounded ice. The core chronology discussed above implies that there was an ice-grounding event on the Plateau in MIS 6 , the Saalian, as well as an earlier early/mid-Pleistocene event (e.g. Flower, 1997; Kristoffersen et al., 2004; Knies et al., 2007). One further observation is important. There is a major difference in the nature of sediment consolidation between the later, MIS 6 icegrounding and the earlier Pleistocene event (O'Regan et al., in press). Sediments from the latter show a high degree of overconsolidation, whereas sediment deformation and/or overconsolidation in the younger sediments is much more subtle.

In detail, there are several possible explanations for the set of seafloor landforms and acoustic units and reflectors associated with MIS 6 on the Yermak Plateau. These include: (a) the flow of a major grounded ice sheet across the plateau crest from Svalbard; (b) the more transient encroachment of relatively thin ice from Svalbard; or (c) the drift across the plateau of megabergs, a set of deep-keeled icebergs trapped in multi-year sea ice, or an ice-shelf remnant derived from a major ice stream or ice shelf elsewhere on the Arctic Ocean margin (Jakobsson et al., in press). Each could arguably have produced the sedimentary record described above.

The orientation of lineations on the crest of the Yermak Plateau is SSE-NNW (Figs. 4 and 8). Ice may have flowed to the NNW from an ice sheet on Svalbard, advancing parallel to the ridge crest on the southern Yermak Plateau. Evidence for grounded ice is restricted to the area of the Plateau crest above about $580 \mathrm{~m}$, which could reflect the strong water-depth control on ice-sheet extent that is related to buoyant forces and increasing rates of mass loss through iceberg production (Thomas, 1979; Benn et al., 2007). However, the lineations are also compatible with a floating ice-shelf remnant or megaberg impinging on the Plateau crest from the NNW (Jakobsson et al., in press; O'Regan et al., in press). This latter explanation is given some support by the down-slope movement of debris flows on the southern side of the crest (Fig. 9), which could have been mobilised by floating ice contacting the floor of the Plateau, which would have been about $120 \mathrm{~m}$ shallower under full-glacial conditions.

Previous studies of the dimensions of the Eurasian Ice Sheet suggest that it was more extensive during the Saalian (MIS 6), prior to the Eemian Interglacial, than during any of its two or three Weischelian advances (Mangerud et al. 1998; Svendsen et al., 2004; Winkelmann et al., 2008). Ice-rafted layers and other terrigenous indicators from cores taken in the Sophia Basin immediately east of the Yermak Plateau, and elsewhere on the northern margin of Svalbard and eastward to the Russian sector, indicate that major ice advances to the shelf edge north of Eurasia took place in the Late and Mid-Weichselian and the Saalian (e.g. Knies et al., 2001; Winkelmann et al., 2008). Ottesen and Dowdeswell (2009) mapped subglacial lineations, similar to those imaged in Fig. 4, close to the shelf edge of northwesternmost Spitsbergen, together with the grounding zone of what they interpreted as the Late Weichselian ice sheet on Svalbard. It is noteworthy that the direction of lineations, and therefore of ice flow, differs from that on the Yermak Plateau by about $45^{\circ}$ (Fig. 8). The implication is that ice was less extensive at the Last Glacial Maximum, where it reached only to the shelf edge in northwest 
Svalbard, than during an earlier glacial phase where it may have extended over $80 \mathrm{~km}$ further offshore into the area represented by the lineations on the southern Yermak Plateau (Fig. 3). This is consistent with the interpretation that a Saalian ice sheet advanced from Svalbard across the shallowest parts of the Yermak Plateau.

However, while the evidence from submarine landforms and acoustic stratigraphy can be interpreted to suggest that sediments on the crest of the Yermak Plateau were produced by a grounded ice sheet, there is only a modest decrease in porosity and associated increase in shear strength in sediments recovered from the study area; specifically from the upper $19 \mathrm{~m}$ bsf of Site 910 (O'Regan et al., in press). These geotechnical observations contrast sharply with the high shear strength and low void ratios found below the earlier Pleistocene ice-grounding event (Flower, 1997). These differences in geotechnical properties indicate very different basal ice conditions during these two events. Assuming the features were formed subglacially, it is likely that the more recent, MIS 6 ice advance lasted for a relatively short period and/or was of relatively thin ice. This is because the geotechnical properties of recovered sediments do not show the overconsolidation that would be expected after a long ice-sheet residence time during which pore pressures could dissipate under the overburden of the grounded ice (O'Regan et al., in press). We conclude, therefore, that if there was Saalian ice advance across the crest of the Yermak Plateau it must have been a relatively shortlived event that may have been associated with either a transient surge or the brief grounding of a floating ice shelf that extended northwestward from Svalbard at the height of the Saalian glaciation. Cores from across the Arctic Ocean, including offshore of Ellesmere Island and Greenland and the northern Eurasian margin, indicate that ice probably extended across much of the northern Eurasian shelf and north of Greenland and eastern Canada to give enhanced levels of ice-rafted debris in MIS 6 (e.g. Hebbeln and Wefer, 1997; Knies et al., 2001; Spielhagen et al., 2004; Nørgaard-Pedersen et al., 2007; Winkelmann et al., 2008); however, this does not necessarily require ice-sheet grounding on the Yermak Plateau.

A third possible explanation for the observed features on the Yermak Plateau is that they were formed by the drift of an iceshelf remnant, a very large, deep-keeled iceberg or group of bergs trapped in multi-year sea ice (Jakobsson et al., in press). While the direction of ice movement is roughly north of west across the plateau, and thus compatible with ice-sheet flow from Svalbard, the features could also be produced by floating ice impinging on the Plateau crest from the Arctic Basin. Prevailing ocean currents would be likely to take large icebergs produced from the western or northern margin of a Barents Sea ice sheet either north in the Norwegian Current or south-westward in the Transpolar Drift, respectively. Under full-glacial conditions, iceberg drift tracks may have differed from those of today, but icebergs calved into the Arctic Basin would still have to exit via Fram Strait. However, the lineations shown in Fig. 4 are curvilinear and, importantly, appear non-erosive. This contrasts with the relatively straight and sharp-edged features observed on the northern Svalbard margin which are interpreted as a product of ploughing by iceberg keels (Fig. 5b, c).

At present, the simplest explanation of the existing morphological and sedimentary evidence from the Yermak Plateau may be that deep-keeled floating ice, potentially derived from the margins of the Arctic Basin ice shelf proposed by Jakobsson et al. (in press), float out of the Arctic Ocean and ground on the Yermak Plateau during the Saalian period. The only way to rule out, or otherwise, the possibility that a Svalbard ice sheet flowed onto the Yermak Plateau during the Saalian is to fully survey the morphology and stratigraphy of whole area between northwestern Spitsbergen and the Plateau.

\subsection{Sources of deep-keeled icebergs to the Arctic Ocean}

There is much evidence for the ploughing of seafloor sediments by the deep keels of large icebergs on the flanks of the Yermak Plateau (Figs. 5a, 7 and 8). The timing of iceberg ploughing is not easy to date directly, since bergs produce erosional landforms. However, the ploughmarks clearly cross-cut the sedimentary lineations on the Yermak Plateau (Fig. 4), and are therefore most likely to be Weichselian in age. Large ploughmarks are found especially between water depths of about 600 and $800 \mathrm{~m}$, and occasionally to about $1000 \mathrm{~m}$, around the Yermak Plateau (Fig. 8), with smaller features at shallower depths (Figs. 3a and 8). While some of these ploughmarks are over a kilometre wide and several tens of metres deep, they tend to show an irregular pattern of drift (Figs. 3a and 7). Today, only relatively small icebergs, with keels usually less than $100 \mathrm{~m}$, are calved from the $860 \mathrm{~km}$-long ice cliffs of Svalbard and the $2500 \mathrm{~km}$ of ice cliffs on Franz Josef Land (Dowdeswell, 1989; Dowdeswell and Forsberg, 1992; Sharov, 2005; Blaszczyk et al., 2009). The larger ploughmarks on the Yermak Plateau are probably formed by deep-keeled icebergs derived from major ice streams draining the Svalbard-Barents Sea area of a former Eurasian Ice Sheet (Dowdeswell and Siegert, 1999; Svendsen et al., 2004; Ottesen et al., 2005). These icebergs would have drifted north in the Norwegian-Spitsbergen Current from the Barents Seawestern Svalbard margin and westward in the Transpolar Drift from former sources in the Franz Victoria and St. Anna troughs.

By contrast with the crest of the Yermak Plateau, the clearly erosional ploughmarks on the northern Svalbard margin, just over $200 \mathrm{~km}$ to the northeast, form a much more regular pattern (Fig. 5b, c). These linear ploughmarks cover an imaged area of approximately $700 \mathrm{~km}^{2}$ between about 400 and $600 \mathrm{~m}$ of modern water depth (Fig. 3b). Some ploughmarks are over $20 \mathrm{~km}$ long, a kilometre wide and up to $80 \mathrm{~m}$ deep. A particularly important attribute of these ploughmarks is that they appear to form parallel sets, where multiple-keeled icebergs are inferred to have drifted in a NNE-SSW direction across the sedimentary substrate (Fig. 5). The interpretation of these features is that they are formed by one of two processes: either by single huge icebergs with a deep, high-relief base that is rough at a kilometre scale; or by a set of individual deep-keeled icebergs that are trapped in an extensive and thick multi-year seaice floe which provides a uniform pattern of drift.

The latter suggestion is physically possible, but there are few direct modern analogues for the operation of this process in openocean settings. The first example is the melange of icebergs and multi-year sea ice, known as 'sikussak', which forms in some Greenland fjords (Reeh et al., 1999: Dowdeswell et al., 2000; Dowdeswell, in press). The keels of the embedded bergs may be deep (Dowdeswell et al., 1992), but sikussak has rarely been observed in the open ocean beyond the fjords. A second example is the marine-ice derived ice shelves of northern Ellesmere Island, Canada, where glaciers flow into and are embedded within multiyear sea ice, which can be calved to produce drifting 'ice islands' (Dowdeswell and Jeffries, in press). However, these ice shelves and ice islands seldom have keels greater than $100 \mathrm{~m}$. Indeed, the partly grounded ice shelves that Jakobsson et al. (in press) suggest fringe much of Arctic Basin in MIS 6 may also be too thin to provide a viable source for the deepest-keeled icebergs.

Thus, the most obvious sources for icebergs with very deep keels that ploughed the northern Svalbard margin are the fast-flowing ice streams that flowed into the Arctic Ocean from two huge basins draining the northern part of the Barents Sea during Weichselian and earlier glaciations via the Franz Victoria and St. Anna troughs (Vogt et al., 1994; Dowdeswell, 1995; Kleiber et al., 2000; Svendsen et al., 2004; Dowdeswell et al., 2010). The deep-keeled icebergs ploughing the north-eastern edge of the Yermak Plateau may have had 
a similar source. The Franz Victoria ice-sheet drainage basin alone has recently been estimated to have an area of about $100,000 \mathrm{~km}^{2}$ and a flux to the Arctic Ocean margin of approximately $40 \mathrm{~km}^{3} \mathrm{yr}^{-1}$ at the Late Weichselian glacial maximum (Dowdeswell et al., 2010). In addition, it has been observed from the margins of the modern Antarctic Ice Sheet that icebergs with submerged keels greater than about $400 \mathrm{~m}$ are not usually produced by extensive floating ice shelves, but rather by ice streams and fast-flowing outlet glaciers which calve icebergs at or close to the grounding line (Dowdeswell and Bamber, 2007). This is because creep thinning and basal melting tend to reduce shelf thickness to about $300 \mathrm{~m}$ within a few tens of kilometres after ungrounding. Finally, icebergs calved from ice streams in the Bear Island and Storfjorden troughs, although probably deep-keeled, are a less likely source for ploughing of the northern Svalbard margin, given that the Yermak Plateau would obstruct their drift northeastwards (Fig. 2).

\section{Conclusions}

- We present new, high-resolution geophysical evidence on the seafloor morphology and acoustic stratigraphy of the Yermak Plateau and northern Svalbard margin between $79^{\circ} 20^{\prime}$ and $81^{\circ} 30^{\prime} \mathrm{N}$ and $5^{\circ}$ and $22^{\circ} \mathrm{E}$ (Figs. 1 and 2). Geophysical datasets are derived from multibeam bathymetry and sub-bottom acoustic profiling. In addition, the stratigraphy of Ocean Drilling Program (ODP) Leg 151 material and other short cores from the Yermak Plateau are re-examined in the context of our detailed geophysical data.

- Lineations, similar to MSGL and other streamlined subglacial landforms, are mapped on the ridge crest of the southern Yermak Plateau above $580 \mathrm{~m}$ (trending SSE-NNW) (Fig. 4). They are also found, with an orientation different by $45^{\circ}$, on the shelf edge northwest of Spitsbergen (Fig. 8), but this represents a later, Late Weischelian ice advance restricted to the Spitsbergen shelf (Ottesen and Dowdeswell, 2009).

- Iceberg ploughmarks are located on the flanks of the Yermak Plateau, and on the outer, deepening part of the northern Svalbard margin (Fig. 8b). Some ploughmarks are huge, at over $80 \mathrm{~m}$ deep (Fig. 5) and in water as deep as $1000 \mathrm{~m}$ (Fig. 7). Sets of aligned ploughmarks on the northern Svalbard margin are probably formed by multi-keeled megabergs derived from fastflowing ice streams (Fig. 5b). A single moat, interpreted as a current overflow channel, is also found on the Plateau, in an otherwise relatively flat and featureless seafloor terrain.

- Core chronologies suggest that the ice-produced lineations are probably of MIS 6 or Saalian age (Fig. 12), and lie above an older early/mid-Pleistocene erosion surface that likely reflects past advance of a major ice sheet from Svalbard (Flower, 1997).

- There are several possible explanations for the set of seafloor landforms and acoustic units and reflectors associated with MIS 6 on the Yermak Plateau. These include: (a) flow of a major grounded ice sheet across the plateau crest from Svalbard (least likely due to lack of overconsolidation of sediments); (b) the more transient encroachment of relatively thin ice from Svalbard; or (c) the drift across the plateau of megabergs, a set of deep-keeled icebergs trapped in multi-year sea ice, or an iceshelf remnant derived from a major ice stream or ice shelf elsewhere on the Arctic Ocean margin.

- The orientation of lineations on the crest of the Yermak Plateau is SSE-NNW (Figs. 4 and 8). Ice may have flowed to the NNW from an ice sheet on Svalbard, advancing parallel to the ridge crest on the southern Yermak Plateau. Evidence for grounded ice is restricted to the area of the Plateau crest above about $580 \mathrm{~m}$, which could reflect a strong water-depth control on icesheet extent. However, the lineations are also compatible with a floating ice-shelf remnant or megaberg impinging on the Plateau crest from the NNW. This latter explanation is given support by the down-slope movement of debris flows on the southern side of the crest (Fig. 9), which could have been mobilised by floating ice contacting the floor of the Plateau.

\section{Acknowledgements}

This paper is a contribution to the International Arctic Science Committee (IASC) endorsed programme Arctic Palaeoclimate and its Extremes (APEX). UK support was from Natural Environment Research Council Grant NER/T/S/2003/00318 to JAD. Swedish support was provided by the Swedish Research Council (VR), the Swedish Royal Academy of Sciences through a grant financed by the Knut and Alice Wallenberg Foundation and the Bert Bolin Centre for Climate Research at Stockholm University through a grant from FORMAS.

\section{References}

Barnes, P.W., Lien, R., 1988. Icebergs rework shelf sediments to $500 \mathrm{~m}$ off Antarctica. Geology 16, 1130-1133.

Benn, D.I., Warren, C.R., Mottram, R.H., 2007. Calving processes and the dynamics of calving glaciers. Earth Science Reviews 82, 143-179.

Blaszczyk, M., Jania, J.A., Hagen, J.O., 2009. Tidewater glaciers of Svalbard: recent changes and estimates of calving fluxes. Polish Polar Research 30, 85-141.

Canals, M., Urgeles, R., Calafat, A.M., 2000. Deep sea floor evidence of past ice streams off the Antarctic Peninsula. Geology 28, 31-34.

Clark, C.D., 1993. Mega-scale glacial lineations and cross-cutting ice-flow landforms. Earth Surface Processes and Landforms 18, 1-19.

Dowdeswell, J.A., 1989. On the nature of Svalbard icebergs. Journal of Glaciology 35 224-234.

Dowdeswell, J.A., 1995. Comment on: “Deep Pleistocene iceberg plowmarks on the Yermak Plateau: sidescan and $3.5 \mathrm{kHz}$ evidence for thick calving ice fronts and a possible marine ice sheet in the Arctic Ocean". Geology 23, 476-477.

Dowdeswell, J.A. Eurasian Arctic ice shelves and tidewater glacier margins. In Copland, L., Mueller, D., (Eds.), Arctic Ice Shelves and Ice Islands. SpringerVerlag, in press.

Dowdeswell, J.A., Bamber, J.L., 2007. Keel depths of modern Antarctic icebergs and implications for sea-floor scouring in the geological record. Marine Geology 243, 120-131.

Dowdeswell, J.A., Forsberg, C.F., 1992. The size and frequency of icebergs and bergy bits from tidewater glaciers in Kongsfjorden, north-west Spitsbergen. Polar Research 11, 81-91.

Dowdeswell, J.A., Jeffries, M.O. Arctic ice shelves and ice islands: an introduction. In Copland, L., Mueller, D., (Eds.), Arctic Ice Shelves and Ice Islands. SpringerVerlag, in press.

Dowdeswell, J.A., Siegert, M.J., 1999. Ice-sheet numerical modeling and marine geophysical measurements of glacier-derived sedimentation on the Eurasian Arctic continental margins. Geological Society of America Bulletin 111, 1080-1097.

Dowdeswell, J.A., Whittington, R.J., Hodgkins, R., 1992. The sizes, frequencies and freeboards of East Greenland icebergs observed using ship radar and sextant. Journal of Geophysical Research 97, 3515-3528.

Dowdeswell, J.A., Villinger, H., Whittington, R.J., Marienfeld, P., 1993. Iceberg scouring in Scoresby Sund and on the East Greenland continental shelf. Marine Geology 111, 37-53.

Dowdeswell, J.A., Whittington, RJ., Jennings, A.E., Andrews, JT, Mackensen, A Marienfeld, P., 2000. An origin for laminated glacimarine sediments through sea-ice build-up and suppressed iceberg rafting. Sedimentology 47, 557-576.

Dowdeswell, J.A., Ó Cofaigh, C., Pudsey, C.J., 2004. Thickness and extent of the subglacial till layer beneath an Antarctic paleo-ice stream. Geology 32, 13-16.

Dowdeswell, J.A., Ottesen, D., Evans, J., Ó Cofaigh, C., Anderson, J.B., 2008. Submarine glacial landforms and rates of ice-stream collapse. Geology 36, 819-822.

Dowdeswell, J.A., Hogan, K.A., Evans, J., Noormets, R., Ó Cofaigh, C., Ottesen, D., 2010 Past ice-sheet flow east of Svalbard inferred from streamlined subglacial landforms. Geology 38, 163-166.

Eiken, O., Hinz, K. 1993. Contourites in the Fram Strait. Sedimentary Geology 82,15-32.

Flower, B.P., 1997. Overconsolidated section on the Yermak Plateau, Arctic Ocean: ice sheet grounding prior to $660 \mathrm{ka}$ ? Geology 25, 147-150.

Geissler, W.H., Jokat, W., 2004. A geophysical study of the northern Svalbard continental margin. Geophysical Journal International 158, 50-66.

Grosswald, M.G., Hughes, T.J., 1999. The case for an ice shelf in the Pleistocene Arctic Ocean. Polar Geography 23, 23-54.

Hebbeln, D., Wefer, G., 1997. Late Quaternary paleoceanography in the Fram Strait Paleoceanography 12, 65-78.

Hughes, T.J., Denton, G.H., Grosswald, M.G., 1977. Was there a late-Würm Arctic ice sheet? Nature 266, 596-602.

Jakobsson, M., Gardner, J.V., Vogt, P., Mayer, L.A., Armstrong, A., Backman, J., Brennan, R., Calder, B., Hall, J.K., Kraft, B., 2005. Multibeam bathymetric and 
sediment profiler evidence for ice grounding on the Chukchi Borderland, Arctic Ocean. Quaternary Research 63, 150-160.

Jakobsson, M., Marcussen, C., Lomrog Scientific Party, 2008a. Lomonosov Ridge Off Greenland 2007 (LOMROG) - cruise report. In: Special Publication Geological Survey of Denmark and Greenland. Geological Survey of Denmark and Greenland, Copenhagen, p. 122.

Jakobsson, M., Macnab, R., Mayer, L., Anderson, R., Edwards, M., Hatzky, J., Werner Schenke, $\mathrm{H}$. Johnson, P. 2008b. An improved bathymetric portrayal of the Arctic Ocean: implications for ocean modeling and geological, geophysical and oceanographic analyses. Geophysical Research Letters 35. doi:10.1029/ 2008GL033520.

Jakobsson, M., Nilsson, J., O'Regan, M.A., Backman, J., Löwemark, L, Dowdeswell, J.A., Colleoni, F., Marcussen, C., Anderson, L, Bjork, G., Darby, D., Eriksson, B., Hanslik, D., Hell, B., Mayer, L., Polyak, L., Sellen, E., Wallin, A. An Arctic Ocean ice shelf during MIS 6 constrained by new geophysical and geological data. Quaternary Science Reviews, in press.

King, E.C., Hindmarsh, R.C., Stokes, C.R., 2009. Mega-scale glacial lineations beneath a West Antarctic ice stream. Nature Geoscience 2, 585-588. doi:10.1038/ NGEO0581.

Kleiber, H.P., Knies, J., Niessen, F., 2000. The Late Weichsalian glaciation of the Franz Victoria Trough, northern Barents Sea: ice sheet extent and timing. Marine Geology 168, 25-44.

Knies, J., Kleiber, H.-P., Matthiessen, J., Müller, C., Nowaczyk, H., 2001. Marine ice-rafted debris records constrain maximum extent of Saalian and Weichselian ice-sheets along the northern Eurasian margin. Global and Planetary Change 31, 45-64.

Knies, J., Mattiessen, J., Mackensen, A., Stein, R., Vogt, C., Frederichs, T., Nam, S.-I., 2007. Effects of Arctic freshwater forcing on thermohaline circulation during the Pleistocene. Geology 35, 1075-1078.

Knies, J., Mattiessen, J., Vogt, C., Laberg, J.S., Hjelstuen, B.O., Smelror, M., Larsen, E., Andreassen, K., Edvin, T., Vorren, T.O., 2009. The Plio-Pleistocene glaciation of the Barents Sea-Svalbard region: a new model based on revised chronostratigraphy. Quaternary Science Reviews 28, 812-829. doi:10.1016/ j.quascirev.2008.12.002

Kristoffersen, Y., Coakley, B., Jokat, W., Edwards, M., Brekke, H., Gjengedal, J., 2004. Seabed erosion on the Lomonosov Ridge, central Arctic Ocean: a tale of deep draft icebergs in the Eurasia Basin and the influence of Atlantic water inflow on iceberg motion? Paleoceanography 19, PA3006. doi:10.1029/2003PA000985.

Kuijpers, A., Andersen, M.S., Kenyon, N.H., Kunzendorf, H., van Weering, T.C.E., 1998. Quaternary sedimentation and Norwegian Sea overflow pathways around Bill Bailey Bank, northeastern Atlantic. Marine Geology 152, 101-127.

Kuijpers, A., Hansen, B., Hühnerbach, V., Larsen, B., Nielsen, T., Werner, F., 2002. Norwegian Sea overflow through the Faroe-Shetland gateway as documented by its bedforms. Marine Geology 188, 147-164.

Kuijpers, A., Dalhoff, F., Brandt, M.P., Hümbs, P., Schott, T., Zotova, A., 2008. Giant iceberg plow marks at more than $1 \mathrm{~km}$ water depth offshore West Greenland. Marine Geology 246, 60-64.

Lisiecki, L.E., Raymo, M.E., 2005. A Pliocene-Pleistocene stack of 57 globally distributed benthic $\delta^{18} \mathrm{O}$ records. Paleoceanography 2010.10292004 PA001071.

Mangerud, J., Dokken, T., Hebbeln, D., Heggen, B., Ingólfsson, O., Landvik, J.Y., Mejdahl, V., Svendsen, J.I., Vorren, T.O., 1998. Fluctuations of the Svalbard-Barents Sea ice sheet during the last 150000 years. Quaternary Science Reviews 17, 11-42.

Mercer, J.H., 1970. A former ice sheet in the Arctic Ocean. Palaeogeography, Palaeoclimatology and Palaeoecology 8, 19-27.

Myhre, A.M., Thiede, J., Firth, J.V., et al., 1995. In: Proc. ODP, Init. Repts, 151: College Station, TX (Ocean Drilling Program). doi:10.2973/odp.proc.ir.151.1995.

Nørgaard-Pedersen, N., Mikkelsen, M., Kristoffersen, Y., 2007. Arctic Ocean record of last two glacial-interglacial cycles off North Greenland/Ellesmere Island implications for glacial history. Marine Geology 244, 93-108.

Ó Cofaigh, C., Pudsey, C.J., Dowdeswell, J.A., Morris, P., 2002. Evolution of subglacial bedforms along a paleo-ice stream, Antarctic Peninsula continental shelf. Geophysical Research Letters 29. doi:10.1029/2001GL014488.

O’Regan, M., Jakobsson, M., Kirchner, N., Forsberg, C.F. Sediment consolidation and deformation beneath Pleistocene ice-grounding events on the Lomonosov Ridge and Yermak Plateau. Quaternary Science Reviews, in press.

Ottesen, D., Dowdeswell, J.A., 2009. An inter-ice stream glaciated margin: submarine landforms and a geomorphic model based on marine-geophysical data from Svalbard. Geological Society of America Bulletin 121, 1647-1665. doi:10.1130/B26467.1.

Ottesen, D., Dowdeswell, J.A., Rise, L., 2005. Submarine landforms and the reconstruction of fast-flowing ice streams within a large Quaternary ice sheet: the $2,500 \mathrm{~km}$-long Norwegian-Svalbard margin $\left(57^{\circ}-80^{\circ} \mathrm{N}\right)$. Geological Society of America Bulletin 117, 1033-1050.
Polyak, L., Edwards, M., Coakley, B., Jakobsson, M., 2001. Ice shelves in the Pleistocene Arctic Ocean inferred from glacigenic deep-sea bedforms. Nature 410, 453-457.

Rack, FR Bloemendal, J, Wolf-Welling TCW O'Connell, S., Cremer, M Winkler, A., Thiede, J., Black, K., Hood, H., 1996. Development of physical properties relationships, interhole composite depth profiles, and sedimentologic ground truthing of multi-sensor core measurements: a synthesis of results. In: Thiede, J., Myhre, A.M., Firth, J.V., Johnson, G.L., Ruddiman, W.F. (Eds.), Proc. ODP, Sci. Results, 151. TX (Ocean Drilling Program), College Station, pp. 595-626. doi:10.2973/odp.proc.sr.151.149.1996.

Reeh, N., Mayer, C., Miller, H., Thomsen, H.H., Weidick, A., 1999. Present and past climate control on fjord glaciations in Greenland: implications for IRD-deposition in the sea. Geophysical Research Letters 26, 1039-1042.

Sato, T., Kameo, K., 1996. Pliocene to Quaternary calcareous nannofossil biostratigraphy of the Arctic Ocean, with reference to late Pliocene glaciation. In: Thiede, J., Myhre, A.M., Firth, J.V., Johnson, G.L., Ruddiman, W.F. (Eds.), Proc. ODP, Sci. Results, 151. TX (Ocean Drilling Program), College Station, pp. 39-59. doi:10.2973/odp.proc.sr.151.112.1996.

Schoof, C., Clarke, G.K.C., 2008. A model for spiral flows in basal ice and the formation of subglacial flutes based on a Reiner-Rivlin rheology for glacial ice. Journal of Geophysical Research 113, B05204. doi:10.1029/2007JB004957.

Sellén, E., O'Regan, M., Jakobsson, M., 2010. Spatial and temporal Arctic Ocean depositional regimes: a key to the evolution of ice drift and current patterns. Quaternary Science Reviews 29, 3644-3664.

Sharov, A.I., 2005. Studying changes of ice coasts in the European Arctic. GeoMarine Letters 25, 153-166.

Spielhagen, R.F., Baumann, K.H., Erlenkeuser, H., Nowaczyk, N.R., NorgaardPedersen, N., Vogt, C. Weiel, D. 2004. Arctic Ocean deep-sea record of northern Eurasian ice sheet history. Quaternary Science Reviews 23, 1455-1483.

Spiegler, D., 1996. Planktonic foraminifer Cenozoic biostratigraphy of the Arctic Ocean, Fram Strait (Sites 908-909), Yermak Plateau (Sites 910-912), and East Greenland Margin (Site 913). In: Thiede, J., Myhre, A.M., Firth, J.V., Johnson, G.L., Ruddiman, W.F. (Eds.), Proc. ODP, Sci. Results, 151. TX (Ocean Drilling Program), College Station, pp. 153-167. doi:10.2973/odp.proc.sr.151.104.1996.

Svendsen, J.I., Alexanderson, H., Astakhov, V.I., Demidov, I., Dowdeswell, J.A., Funder, S., Gataullin, V., Henriksen, M., Hjort, C., Houmark-Nielsen, M., Hubberten, H.W., Ingólfsson, O., Jakobsson, M., Kjær, K.H., Larsen, E., Lokrantz, H., Lunkka, J.P., Lyså, A., Mangerud, J., Matioushkov, A., Murray, A., Möller, P., Niessen, F., Nikolskaya, O., Polyak, L., Saarnisto, M., Siegert, C., Siegert, M.J., Spielhagen, R.F., Stein, R., 2004. Late Quaternary ice-sheet history of Northern Eurasia. Quaternary Science Reviews 23, 1229-1271.

Syvitski, J.P.M., Stein, A.B., Andrews, J.T., 2001. Icebergs and the sea floor of the East Greenland (Kangerlussuaq) continental margin. Arctic, Antarctic, and Alpine Research 33, 52-61.

Thiede, J., Myhre, A.M., Firth, J.V., Johnson, G.L., Ruddiman, W.F. (Eds.), 1996. Proc. ODP, Sci. Results, 151. TX (Ocean Drilling Program), College Station. doi:10.2973/ odp.proc.sr.151.1996.

Thierstein, H.R., Geitzenauer, K.R., Molfino, B., Shackleton, N.J., 1977. Global synchroneity of late Quaternary coccolith datums levels: validation by oxygen isotopes. Geology 5, 400-404.

Thomas, R.H., 1979. Ice shelves: a review. Journal of Glaciology 24, 273-286.

Vanneste, M., Mienert, J., Bünz, S., 2006. The Hinlopen slide: a giant, submarine slope failure on the northern Svalbard margin, Arctic Ocean. Earth and Planetary Science Letters 245, 373-388.

Vogt, P.R., Crane, K., Sundvor, E., 1994. Deep Pleistocene iceberg ploughmarks on the Yermak Plateau: sidescan and $3.5 \mathrm{kHz}$ evidence for thick calving ice fronts and a possible marine ice sheet in the Arctic Ocean. Geology 22, 403-406.

Vogt, C., Knies, J., Spielhagen, R.F., Stein, R., 2001. Detailed mineralogical evidence for two nearly identical glacial/interglacial cycles and Atlantic water advection to the Arctic Ocean during the last 90,000 years. Global and Planetary Change $31,23-44$.

Winkelmann, D., Jokat, W., Niessen, F., Stein, R., Winkler, A., 2006. Age and extent of the Yermak Slide north of Spitsbergen, Arctic Ocean. Geochemistry, Geophysics, Geosystems 7. doi:10.1029/2005GC001130.

Winkelmann, D., Stein, R., 2007. Triggering of the Hinlopen/Yermak Megaslide in relation to paleoceanography and climate history of the continental margin north of Spitsbergen. Geochemistry, Geophysics, Geosystems 8. doi:10.1029/ 2006 GC001485.

Winkelmann, D., Schafer, C., Stein, R., Mackensen, A., 2008. Terrigenous events and climate history of the Sophia Basin, Arctic Ocean. Geochemistry, Geophysics, Geosystems 9. doi:10.1029/2008GC002038.

Woodworth-Lynas, C.M.T., Simms, A., Rendell, C.M., 1985. Iceberg grounding and scouring on the Labrador Continental Shelf. Cold Regions Science and Technology $10,163-186$. 